ROCZNIKI HUMANISTYCZNE

Tom LXVIII, zeszyt 2 - 2020

DOI: http://dx.doi.org/10.18290/rh20682-4

ANDRZEJ PRZEGALIŃSKI

\title{
ZANIM DO LUBLINA ZAWITAŁ WIELKI PRZEMYSŁ - DZIEJE GOSPODARCZE MIASTA W EPOCE MIĘDZYPOWSTANIOWEJ (1831-1863) STUDIUM SYNTETYCZNE
}

Z dedykacja dla Pani Doktor Zofii Gołębiowskiej

Niniejszy artykuł, pomyślany jako tekst dwuczęściowy, ma na celu przybliżenie czytelnikom dziejów gospodarczych Lublina w epoce dla Królestwa Polskiego szczególnej: po upadku powstania listopadowego, w okresie nasilającego się paskiewiczowskiego ucisku (1832-1856) i kilku lat odwilży poprzedzających wybuch insurekcji styczniowej. Ówczesny rozwój miasta oraz kondycja przemysłu, rzemiosła i handlu, w zestawieniu z rozkwitem Lublina $\mathrm{w}$ epoce postyczniowego półwiecza, były niewątpliwie skromne i niezbyt efektowne. $Z$ tych względów rola tego okresu w dyskusjach o gospodarczych wzlotach grodu nad Bystrzycą bywa niekiedy pomniejszana. Niesłusznie. W epoce międzypowstaniowej miasto rozwijało się wprawdzie umiarkowanie dynamicznie, ale i wówczas dokonywały się przecież ważkie przekształcenia urbanistyczne, nie brakło też innowatorów oraz ciekawych, choć nie zawsze fortunnych inicjatyw przemysłowych. To także wtedy związała się z Lublinem część przedsiębiorców, którzy w latach późniejszych zbudowali markę tutejszej industrializacji.

Dr hab. ANDRZEJ PrZEGAliŃSKI - Uniwersytet Marii Curie-Skłodowskiej w Lublinie, Wydział Humanistyczny, Instytut Historii, Zakład Historii XIX wieku i Dziejów Europy Wschodniej; adres do koresponencji — e-mail: andrzejprzegalinski@o2.pl; ORCID: https://orcid.org/00000002-6255-0417. 


\section{CZĘŚĆ PIERWSZA: MIASTO I LUDZIE*}

Spokojny i stosunkowo długotrwały rozwój Lublina w epoce konstytucyjnego Królestwa Polskiego, znaczony gruntownym porządkowaniem przestrzeni miejskiej, rozwojem budownictwa i infrastruktury usługowej oraz krzepnięciem przemysłu i rzemiosła ${ }^{1}$, przerwał wybuch powstania listopadowego, które dla miasta i regionu miało konsekwencje wprost dramatyczne. W następstwie działań wojennych, a więc toczonych bitew, przemarszów i kwaterunków armii, podpaleń, wreszcie różnych rekwizycji i kontrybucji uległa zniszczeniu znaczna część województwa, a w szczególności obwodu lubelskiego ${ }^{2}$. Fryderyk Skarbek (ekonomista, polityk, literat i historyk) przejeżdżający w końcu września 1831 roku, a więc już po kapitulacji Warszawy, przez Podlasie i północną część Lubelszczyzny ze smutkiem patrzył na wojenne zgliszcza. Pisał:

Po przejeździe granicy Królestwa zwłaszcza poczynając od Międzyrzeca, jeszcze więcej rażący widok spustoszenia przedstawiał się naszym oczom; drogi i mosty popsute i pozrywane; wszelkie przeprawy przez rowy i wody, bądź utrudnione, bądź całkiem nie do przebycia; po obu stronach traktu sterczące kominy po spalonych w zupełności wioskach; wszędzie ślady koczowisk i obozów, a nigdzie śladu uprawy i pracy ludzkiej; pola w odłogach lub bez zassiewów, koleinami armatnimi tylko poorane; wreszcie jak tylko oko sięgnąć mogło, ani człowieka, ani żadnej żyjącej istoty na tych rozległych obszarach; wszędzie pusto i głucho; zupełnie grobowa cisza, którą liczne mogiły i kościotrupy padłych koni co chwila przypominały"3.

Znaczące straty poniosły nadwiślańskie miasta i wsie, przede wszystkim Puławy wraz z Końskowolą, Kazimierz, Józefów, Kurów i Garbów, pożar strawił Lubartów i część Markuszowa. W Lublinie, na przedmieściu Kalinowszczyzna, w skutek nieopatrznego wysadzenia arsenału polowego przez

\footnotetext{
* Część druga, nosząca podtytuł „Przemysł, rzemiosło i handel”, ukaże się w kolejnym tomie „Roczników Humanistycznych” z. 2.

${ }^{1}$ M.A.R., Ilustrowany przewodnik po Lublinie, Warszawa 1901, s. 187-189; Z. BowNIK, Kupiectwo lubelskie 1317-1959, Lublin 1960, s. 117; T. MENCEL, Lublin przedkapitalistyczny, w: Dzieje Lublina. Próba syntezy, t. I, red. J. Dobrzański, J. Kłoczowski, J. Mazurkiewicz, Lublin 1965, s. 202-203; H. GAWARECKI, O dawnym Lublinie, Lublin 1974, s. 85-90; B. MiKULEC, Wśród pionierów polskiego przemystu, w: Lublin $w$ dziejach i kulturze Polski, red. T. Radzik i A.A. Witusik, Lublin 1997, s. 174-175; W. ŚLADKOWSKI, W epoce zaborów, w: T. RADZIK, W. ŚLADKOWSKI, G. Wóscikowski, W. Wóscikowski, Lublin. Dzieje miasta, t. II: XIX-XX wiek, Lublin 2000, s. 27-33.

${ }^{2}$ T. Mencel, Między powstaniami (1831-1864), w: Dzieje Lubelszczyzny, t. I, red. T. Mencel, Warszawa 1974, s. 545; W. BeDNARSKI, Straty wojenne Lubelszczyzny i Podlasia w powstaniu listopadowym, w: $W$ kręgu zainteresowań naukowych profesora Tadeusza Mencla, red. A. Koprukowniak, Lublin 1999, s. 221, 227; J. SKARBEK, Województwo lubelskie w powstaniu listopadowym 1830-1831, cz. 2, Lublin 2013, s. 386-387, 390, 395, 400.

${ }^{3}$ Pamiętnik Fryderyka hrabiego Skarbka, Poznań 1878, s. 198.
} 
stacjonujący na Tatarach 5. Korpus Rezerwowy Kawalerii gen. Cypriana Kreutza, spłonęło 11 domów i klasztor z kościołem Augustianów, ucierpiało Podzamcze, zniszczono folwarki miejskie Bronowice i Ponikwodę. Na południu Lubelszczyzny „puszczono z dymem” dużą część Szczebrzeszyna i Zamościa. Wokół twierdzy zamojskiej w czasie oblężenia zniszczono ogromne połacie pól uprawnych, przedmieścia utraciły ponad 200 dymów, spalono kilka okolicznych wsi. Na Podlasiu ucierpiały przede wszystkim miasta i wsie leżące przy trakcie brzesko-litewskim - głównie okolice Kocka, Łukowa, Parysewa, Ryk, Seroczyna, Wodynia, Węgrowa i Żelechowa oraz wioski nad Bugiem i Wieprzem, gdzie konnica rosyjska stratowała zasiewy ${ }^{4}$.

Antoni Meliton Rostworowski z Milejowa, były oficer artylerii konnej Księstwa Warszawskiego, uczestnik wojny z Austrią w 1809 roku, inwalida z kampanii rosyjskiej 1812 roku (stracił wówczas rękę), mianowany przez władze zaborcze jesienią 1831 roku (po raz wtóry) prezesem kapitulanckiej Komisji Województwa Lubelskiego (KWL) ${ }^{5}$, w taki oto sposób w połowie grudnia tego roku opisał kondycję rolnictwa.

Stan rolnictwa przez ciąg trwającej wojny znacznie ucierpiał. Zapasy zboża, szczególniej pod Twierdzą Zamościem z powodu oblężenia tejże przez dwa korpusy Cesarsko-Rosyjskie i okolice Nadwiślańskie przez przechody Korpusu [Girolamo] Ramorino i ścigających go wojsk

\footnotetext{
${ }^{4}$ Archiwum Główne Akt Dawnych (dalej: AGAD), Komisja Rządowa Spraw Wewnętrznych (dalej: KRSW), sygn. 7088, k. 29-29v.; T. MenCEL, Między powstaniami, s. 545; W. ĆWIK, Z dziejów Lubartowa w latach 1796-1866, w: Lubartów. Z dziejów miasta i regionu, red. S. Tworek, Lublin 1977, s. 55; W. Śladkowski, Zamość pod znakiem Marsa, w: Czterysta lat Zamościa, red. J. Kowalczyk, Wrocław-Warszawa-Kraków-Gdańsk-Lódź 1983, s. 126-127; TENŻE, $W$ epoce zaborów, s. 53; S. WIŚNIEWSKI, Pod rządami zaborców 1795-1918, w: Dzieje Końskowoli, red. R. Szczygieł, Lublin 1988, s. 91-92; W.W. BEDNARSKI, Z dziejów klęsk elementarnych na Podlasiu w latach 1815-1831, „Radzyński Rocznik Humanistyczny” 1 (2001), s. 109-111; D. TAźBIREK, Lublin w czasie powstania listopadowego, Lublin 2009, s. 158.

${ }^{5}$ W. ĆWIK, J. REDER, Lubelszczyzna. Dzieje rozwoju terytorialnego, podziałów administracyjnych i ustroju władz, Lublin 1977, s. 90-91; T. Mencel, Powstanie listopadowe na Lubelszczyźnie w świetle raportu Komisji Województwa Lubelskiego z 9 czerwca 1834 r., „Rocznik Lubelski” 22 (1980), s. 128-131; S.J. RostworowsKi, Monografia rodziny Rostworowskich. Lata 1386-2012, t. II, Warszawa 2013, s. 1680-1681, 1689. A.M. Rostworowski po raz pierwszy stanął na czele tzw. „Nieprzyjacielskiej” Komisji Wojewódzkiej w lutym 1831 roku. Mianowania dokonał 10. tego miesiąca rosyjski generał Cyprian Kreutz, co następnie potwierdził feldmarszałek Iwan Dybicz. Tego samego dnia prezesem powstańczej „Narodowej” Komisji Wojewódzkiej został Kajetan Morozewicz, który zastąpił na tym stanowisku Ignacego Lubowieckiego. Na wieść o zbliżającym się do Lublina korpusie gen. Wojciecha Chrzanowskiego, Rostworowski 10 maja uciekł z miasta i wyjechał na Wołyń. Zob. T. Mencel, Działalność władz cywilnych województwa lubelskiego w okresie powstania listopadowego, „Rocznik Lubelski” 5 (1962), s. 121-122, 131, 142; TENŻE, Kajetan Morozewicz (1792-1869) prezes „Narodowej” Komisji Województwa Lubelskiego w powstaniu listopadowym, „Rocznik Lubelski” 20 (1980), s. 15, 17.
} 
całkowicie wyniszczone i wyzute zupełnie z siana, owsa i słomy. W ogólności część województwa poczynając od Kocka aż do ujścia Wieprza do Wisły, tudzież gminy przy traktach głównych, jako to od Puław na Lublin, Łęczną do Włodawy, od Lublina na Krasnystaw, Uchanie do Hrubieszowa, od Krasnegostawu do Zamościa, tudzież z Lublina na Lubartów do Kocka, na Bełżyce, Urzędów do Wisły, z Bełżyc na Wronów i dalej do Wisły, wszystkie te okolice ucierpiały wiele na spodziewanym zbiorze, gdyż zboże w trawie jeszcze będące częścią wypaszone, częścią wykoszone zostało, włościanie odrywani od pracy"6.

Gdy opadł bitewny kurz i dopaliły się pogorzeliska, na chłodno oszacowano powstańcze straty. W województwie lubelskim ubytki w zbożu zostały wyliczone na 1002692 złp, w inwentarzu żywym - na 1344698 złp. W czasie powstania ubyło $21,6 \%$ koni, $25 \%$ owiec, $40 \%$ bydła rogatego i aż $72 \%$ trzody chlewnej. Ogólnie rzecz biorąc, z tytułu różnych „zaborów w podatkach", kontrybucji wojennych, wyniszczenia pól, spalenia domów i rekwizycji inwentarza (żywego i martwego) utracono potencjał szacowany na ogromną sumę $15708865 \mathrm{zlp}^{7}$.

Dramatyczne położenie rolnictwa i wielu mieszkańców miast i miasteczek, którzy w znacznym odsetku utrzymywali się z pracy na roli, potęgował fakt, że rok $1830 \mathrm{w}$ Królestwie, a zwłaszcza w jego południowej części, stał pod znakiem klęski głodu, którą poprzedziła ostra i długa zima. Dawał się także odczuć ubytek rąk do pracy, będący konsekwencja, charakterystycznego dla czasu wojny, wyludnienia wsi ${ }^{8}$. Jesienią $1831 \mathrm{r}$. wieś stanęła przed widmem głodu - brak było zboża na zasiewy i siły pociągowej do uprawy gruntów. Co gorsza, ogół mieszkańców dotykały choroby epidemiczne przede wszystkim cholera. Zaraza została przywleczona przez wojska rosyjskie zimą 1831 r. i zbierała śmiertelne żniwo głównie wśród Żydów oraz w mieszanych miasteczkach w obwodzie zamojskim i krasnostawskim? .

\footnotetext{
${ }^{6}$ AGAD, KRSW, sygn. 7088, k. 34v.-35.

${ }^{7}$ Tamże, k. 30; T. MENCEL, Między powstaniami, s. 545.

${ }^{8}$ Ogólnie rzecz biorąc, w 1830 r. mieszkało w województwie lubelskim 495768 osób, w 1832 r., wedle różnych szacunków - od 469894 do 470 232. W ciągu dwóch lat ubyło więc ponad 25500 mieszkańców. W kolejnej dekadzie prawidłowość ta uległa na szczęście odwróceniu i liczba ludności zaczęła szybko wzrastać. W 1833 r. żyły tu już 475472 osoby, pięć lat później - 530199 , a w 1844 r. - 573317 osób. Zob. H. WIERCIEŃSKI, Opis statystyczny guberni lubelskiej, Warszawa 1901, s. 109; Historia Polski w liczbach. Ludność. Terytorium, red. A. Jezierski, Warszawa 1994, s. 71; J.K. JANCZAK, Statystyka ludności Królestwa Polskiego (1830-1844), „Przeszłość Demograficzna Polski” 16 (1985), s. 34; T. MenCEL, Miedzy powstaniami, s. 546-547.

${ }^{9}$ Do Lublina cholera „zawitała” wraz z wojskami rosyjskimi gen. Cypriana Kreutza, które 8 lutego 1831 r. zajęły miasto. Najeźdźca wycofał się wprawdzie 4 marca, uchodząc przed wkraczającym do stolicy województwa korpusem gen. Józefa Dwernickiego, ale już 11 dnia tego miesiąca ponownie objął miasto wespół z resztkami korpusów gen. Iwana Witta i Edwarda de Tolla. Począwszy od kwietnia, kiedy choroba zaczęła przybierać na sile, umierało codziennie 50-60 żołnierzy. Zaraza dotknęła też ludność cywilną - głównie mieszkających na Podzamczu Żydów,
} 
Morowe powietrze ustąpiło wprawdzie na chwilę w 1832 r., ale już trzy lata później pojawiło się ponownie nad Lublinem, Hrubieszowem i Horodłem. Mniejsze ogniska cholery odżywały rokrocznie w różnych miejscowościach Lubelszczyzny. Systematycznie, co kilka lat towarzyszyły im ponawiające się klęski żywiołowe i pomory żywego inwentarza. Trudne, a niekiedy wręcz rozpaczliwe położenie ogółu ludności osiągnęło swe apogeum w szóstej dekadzie XIX wieku wraz z szalejącą ponownie w latach 1852-1855 cholerą. Epidemia wybuchła najpierw w Lublinie, w dzielnicy żydowskiej, gdzie utrzymujące się od dziesięcioleci fatalne warunki sanitarne i nadmierne zagęszczenie ludności sprzyjały szybkiemu rozprzestrzenianiu się choroby. Przerażeni Żydzi uciekali do miasteczek i wsi, niosąc z sobą śmiertelny powab. O zasięgu i sile rozprzestrzeniania się zarazy świadczył fakt, że cholera objęła 55 miast i 132 gminy w guberni, zabijając ponad połowę zarażonych. W Lublinie w 1852 r. zmarło ogółem 1615 osób, trzy lata później - 1859, i były to największe wartości roczne zgonów w całym okresie międzypowstaniowym. Dla dopełnienia tego ciemnego obrazu należy dodać, że w 1855 r. cholerze towarzyszyły epidemia tyfusu i gorączki tyfoidalnej (tularemii), które w guberni położyły trupem ponad 10000 osób $^{10}$.

W dziedzinie przeobrażeń administracyjnych dotyczących epoki polistopadowego trzydziestolecia zmieniło się w Królestwie i na Lubelszczyźnie wiele, choć można by sądzić, że były to zmiany li tylko w nazewnictwie. I tak w następstwie przekształceń zmierzających do likwidacji odrębności ustrojowych kraju i upodobnienie Królestwa do wzorów rosyjskich ukazem z 25 lutego (7 marca) 1837 r. ${ }^{11}$ przemianowano województwa na gubernie.

którzy szukając ratunku, masowo uciekali na prowincję - głównie do Tarnogrodu i Biłgoraja. W ciągu zaledwie 13 dni (od 15 do 27 kwietnia) cholera zabiła w Lublinie 126 starozakonnych. Druga fala epidemii, wyraźnie już słabsza, została odnotowana w maju i czerwcu. Zob. T. MENCEL, Działalność władz cywilnych, s. 126, 128, 130; W. ŚLADKOwSKI, Lublin powstańczy, w: Lublin w dziejach, s. 196; J. SKARBEK, Żydzi Lublina podczas powstania listopadowego 1830-1831, w: Żydzi w Lublinie, t. II, red. T. Radzik, Lublin 1998, s. 149-151.

${ }^{10}$ L. WolsKi, Materiały do statystyki Królestwa Polskiego, „Biblioteka Warszawska” t. II, 1850, s. 225; J. WiLlaUME, Z dziejów wsi lubelskiej przed uwłaszczeniem, „Annales UMCS”, sec. F, vol. X, 1955, s. 94; T. MENCEL, Między powstaniami, s. 548-549, 564, 569-570; TENŻE, Lublin w okresie walk narodowowyzwoleńczych 1795-1864, w: Lublin 1317-1967, red. H. Zins, Lublin 1967, s. 134; TENŻE, Wieś pańszczyźniana w Królestwie Polskim w połowie XIX wieku, Lublin 1988, s. 235-236, 244-245; W. ZAJEwSKI, Powstanie listopadowe 1830-1831, w: S. KIENIEIWCZ, A. ZAHORSKI, W. ZAJEWSKI, Trzy powstania narodowe: kościuszkowskie, listopadowe, styczniowe, Warszawa 2000, s. 232; A. SzMYT, Krzemieńczanin Karol Kaczkowski - naczelny lekarz armii powstańczej, w: Powstanie listopadowe 1830-1831. Dzieje-historiografia-pamięć, red. T. Skoczek, Warszawa 2015, s. 43; W. ŚLADKOWSKI, W epoce zaborów, s. 62.

${ }^{11}$ Daty wydania najważniejszych aktów prawnych będą podawane w dwóch obowiązujących w zaborze rosyjskim stylach (porządkach): juliańskim i gregoriańskim - przyp. aut. 
Lublin z miasta wojewódzkiego stał się wówczas stolicą guberni. Nieco wcześniej, bo z dniem 16 listopada 1836 r., otrzymał dymisję prezes KWL A.M. Rostworowski. Pierwszym gubernatorem cywilnym guberni lubelskiej został Rosjanin Marek Albertow (1837-1851) - ożeniony zresztą z Polką, władający językiem polskim i Polakom życzliwy. W 1842 r. obwody przekształcono w powiaty (z rosyjska ujezdy), powiaty zaś w okręgi (odpowiedniki rosyjskich okrugów). Lublin, siedziba obwodu, został wtedy centrum powiatu. Wreszcie na mocy ukazu z 9 (21) sierpnia 1844 r. z dniem 1 stycznia 1845 r. włączono do guberni lubelskiej Podlasie, czyli gubernię podlaską. W ten sposób obszar ścisłego międzyrzecza Wisły i Bugu został poszerzony o powiaty: bialski, łukowski, radzyński i siedlecki, liczba miast wzrosła z 59 do 104, rozległość zaś z 99551 włók $(16716$ km²) do 187711 włók $\left(31520 \mathrm{~km}^{2}\right)^{12}$.

Lublin, boleśnie doświadczony w czasie insurekcji, poddany przez większą jej część okupacji rosyjskiej, zaczął z wolna dźwigać się z upadku. Powstańcze straty miasta, będące rezultatem różnych rekwizycji i zaborów, grabieży mienia i zbóż ${ }^{13}$, wreszcie dewastacji nieruchomości i pożarów, wyniosły 278969 złp. Stolicy województwa ciążyło przy tym dość duże zadłużenie, stanowiące pokłosie przeprowadzonej w epoce konstytucyjnej przebudowy i rozbudowy, czyli wspomnianej wyżej melioracji. Ogół przygniatał narzucony przez Mikołaja I i forsowany przez namiestnika hr. Iwana Paskiewicza system rządów. W ramach popowstaniowych represji administrację na szczeblu miast i województw poddano władzom wojskowym, wraz z upływem lat ograniczono, a później faktycznie zniesiono samorząd miejski. Zastraszonym mieszkańcom towarzyszyło nieznośne poczucie wszechobecnej kontroli i inwigilacji. Realizowała tę politykę zreorganizowana i sukcesywnie rozbudowywana żandarmeria wraz z pozostającymi na jej

\footnotetext{
${ }^{12}$ Dziennik Praw Królestwa Polskiego (dalej: DPKP), t. XX, b.m.d.w., s. 413-417; DPKP, t. XXX, b.m.d.w., s. 281-285; DPKP, t. XXXIV, b.m.d.w., s. 453-459; H. ŁoPACIŃSKI, Podziaty administracyjne teraźniejszej guberni lubelskiej w różnych czasach, „Pamiętnik Lubelski. Kalendarz Ilustrowany" na rok 1904, Lublin 1904, s. 24; W. ĆWIK, J. REDER, Lubelszczyzna, s. 93; H. WIERCIEŃSKI, Pamiętniki, oprac. A. Zajączkowski, Lublin 1973, s. 56; T. MENCEL, Wieś pańszczyźniana, s. 18; TENŻE, Między powstaniami, s. 546; S.J. RostworowsKi, Monografia rodziny Rostworowskich, s. 1696.

${ }^{13}$ Za większość zaborów i rekwizycji odpowiadały, wysługujące się Rosjanom, władze miejskie. Warto przypomnieć, że gen. Kreutz nie dopuścił do zrabowania Lublina, nałożył na mieszkańców tylko kontrybucję w postaci 1000 par butów i 250 pudów smarowidła do armat i wozów. Do większego rozprężenia doszło za czasów jego następcy, gen. Józefa Hurki, który latem $1831 \mathrm{r}$. został naczelnikiem wojennym województwa lubelskiego. Zob. T. MENCEL, Działalność władz cywilnych, s. 128-129; TENŻE, Organizacja i działalność administracji miejskiej w Lublinie w latach 1809-1866, ,Rocznik Lubelski” 4 (1961), s. 80.
} 
usługach prowokatorami i szpiegami oraz współdziałająca z żandarmami policja miejska ${ }^{14}$.

Odzyskiwaniu stabilności gospodarczej nie sprzyjali ówcześni włodarze Lublina, których sylwetki - jak pisał Wiesław Śladkowski - „namalować by można jedynie czarnymi barwami" ${ }^{\prime 15}$. Prezydent Tadeusz Kossakowski (1830-1835), dawny kapitan inwalidów wojsk polskich (w czasie służby wojskowej stracił nogę), zasłynął w czasie powstania jako organizator finansowanych przez miasto wystawnych przyjęć dla carskich oficerów i generałów. Później dał się poznać jako powolny wobec władz zaborczych łapówkarz i malwersant, a jego rządy zapisały się całkowitym paraliżem miejskiej administracji. Następcami Kossakowskiego byli kolejni, pełni buty i arogancji dymisjonowani oficerowie rosyjscy, którzy także nie mieli kwalifikacji do zarządzania miastem: brutal i awanturnik, wrogo nastawiony do ludności żydowskiej, zniemczony polski szlachcic Albert Paczyński (1836-1838), w mniejszym może stopniu zruszczony szlachcic z witebskiego Edward de Toll (1838-1847), który zapisał się w czasie tłumienia powstania na Lubelszczyźnie, oraz emerytowany kapitan Mikołaj Górecki (1847-1855). Pierwszym zawodowym urzędnikiem na stanowisku prezydenta został dopiero radca dworu Józef Białobłocki (wcześniej naczelnik Sekcji Wyznań i Oświecenia Publicznego przy Rządzie Gubernialnym Lubelskim), pełniący tę godność w latach $1855-1861^{16}$.

Polistopadowy Lublin ucichł więc ciszą złowrogą, napełnił przestrzeń miejską strachem i wzmagającą się atmosferą terroru. Ignacy Baranowski, lekarz i społecznik, profesor Uniwersytetu Warszawskiego, pamiętający miasto z czasów dzieciństwa na przełomie lat 30. i 40. XIX wieku, napisał w swoim pamiętniku:

\footnotetext{
${ }^{14}$ Pamiętnik Ignacego Baranowskiego (1840-1862), wyd. A. Wrzosek, Poznań 1923, s. 7, 9-10; H. WierCieŃSKI, Pamiętniki, s. 65-66; T. Mencel, Organizacja i działalność, s. 79-80; TENŻE, Lublin przedkapitalistyczny, s. 205, 208; E. KACZYŃSKA, D. DREWNIAK, Ochrana. Carska policja polityczna, Warszawa 1993, s. 25-26; S. WIECH, Żandarmeria rosyjska i jej raporty, w: Sytuacja polityczna Królestwa Polskiego w świetle tajnych raportów naczelników Warszawskiego Okręgu Żandarmerii z lat 1867-1872 i 1878, oprac. S. Wiech i W. Caban, Kielce 1999, s. 13-14; W. ŚLADKOWSKI, $W$ epoce zaborów, s. 53; TENŻE, Lublin powstańczy, s. 195-197; D. TAŹBIREK, Lublin w czasie powstania listopadowego, s. 157-159.

${ }^{15}$ W. ŚladKOWSKI, W epoce zaborów, s. 54.

${ }^{16}$ M. GawareckA, Prezydenci miasta Lublina $w$ latach 1830-1880, „Życie Lubelskie”, 1949 , nr 25, s. 3; T. MENCEL, Organizacja i działalność, s. 80-81, 87-88; TENŻE, Lublin przedkapitalistyczny, s. 207; W. ŚladKOWSKI, W epoce zaborów, s. 54, 56; G. FIGIEL, Miasto między powstaniami $i$ w czasie styczniowej insurekcji, w: Lublin. 700 lat dziejów miasta, red. G. Figiel, R. Szczygieł, W. Śladkowski, Lublin 2017, s. 166-167.
} 
Te moje pierwsze wrażenia - to są stare mury, wieże wyniosłe, bramy odwiecznej fortecy, kościoły, których nawy ogromnymi się dziecku małemu wydawały; po części zrujnowane, stare pałace noszące nazwę Czartoryskich, Radziwiłłów, Sapiehów; wreszcie mury po skasowanych klasztorach zamienione jedne na koszary wojskowe, inne na fabryki, inne na siedziby najbiedniejszej ludności żydowskiej; przy tym ulice wąskie, prawie bez ruchu kołowego, figury posuwające się krokiem powolnym, wiecznie te same. Jakaś cisza ponura, atmosfera ciężka, jakby dusząca ${ }^{17}$.

W podobnym tonie wypowiadał się Seweryn Zenon Sierpiński, który w swoim pionierskim, wydanym w 1839 r. Obrazie Miasta Lublina zauważył, że:

Na mieście panuje cisza, wszyscy w ponurym milczeniu przechodzą po ulicach, nie masz tu huku pojazdów, nie słychać dzwonków zimowych jak w Warszawie i innych miastach stołecznych ${ }^{18}$.

Po powstaniu Lublin opustoszał, szlachta bowiem, dawniej chętnie i licznie skupiająca się w mieście, przeniosła się na wieś. Wielu opuściło miasto w czasie wojny, inni, z różnych względów, do Lublina już nie powrócili. Liczba ludności stałej, wynosząca w 1830 r. 13894 osoby, spadła do 12701 w 1833 r. W kolejnym roku miasto liczyło już 13266 osób, niemniej stan przedpowstaniowy osiągnęło dopiero z końcem lat 30. W $1843 \mathrm{r}$. w stolicy guberni mieszkało 14518 osób, u schyłku dekady - 14 948. W 1855 r. wykazano tu 15489 mieszkańców, dwa lata później - 16056 osób, na przełomie 1860/1861 r. - 19 054, w 1863 r., wedle przybliżonych szacunków, od 19 344 do 19745 osób. Przyrost liczby ludności był więc dostrzegalny, niemniej przez większą część epoki charakteryzował się rozwojem na ogół powolnym ${ }^{19}$.

\footnotetext{
${ }^{17}$ Pamiętnik Ignacego Baranowskiego, s. 2.

${ }^{18}$ S.Z. SIERPIŃSKI, Obraz miasta Lublina, Warszawa 1839, s. 17-18.

${ }^{19}$ Raport Urzędu Municypalnego miasta Lublina do Komisji Województwa Lubelskiego z działalności za rok 1833, w: Lublin w dokumencie 1317-1967, oprac. F. Cieślak, H. Gawarecki, M. Stankowa, Lublin 1976, s. 129; B. KoŁODZIŃSKI, Geografia Królestwa Polskiego podlug najnowszych źródet skreślona, Warszawa 1863, s. 59; Stownik Geograficzny Królestwa Polskiego i innych krajów stowiańskich (dalej: SGKP), t. V, red. F. Sulimierski, B. Chlebowski, W. Walewski, Warszawa 1884, s. 421; S.Z. SierPIŃSKI, Obraz miasta Lublina, s. 12; H. WiERCIEŃSKI, Opis statystyczny, s. 126-127; T. MENCEL, Organizacja administracj, s. 55-56, 59; TENŻE, Lublin w okresie, s. 134; R. BENDER, Powstanie czy samorzad? Rady miejskie i powiatowe w Lubelskiem 1961-1863, Lublin 1998, s. 70; A. KOPRUKOWNIAK, Obraz miasteczek Lubelskich 1795-1918, w: Miejskie spoleczności lokalne w Lubelskiem 1795-1918, red. A. Koprukowniak, Lublin 2000, s. 16; W. ŚLADKOWSKI, Sprawozdanie gubernatora lubelskiego za rok 1863, „Rocznik Lubelski” 6 (1963), s. 231; TENŻE, Wepoce zaborów, s. 58-59.
} 


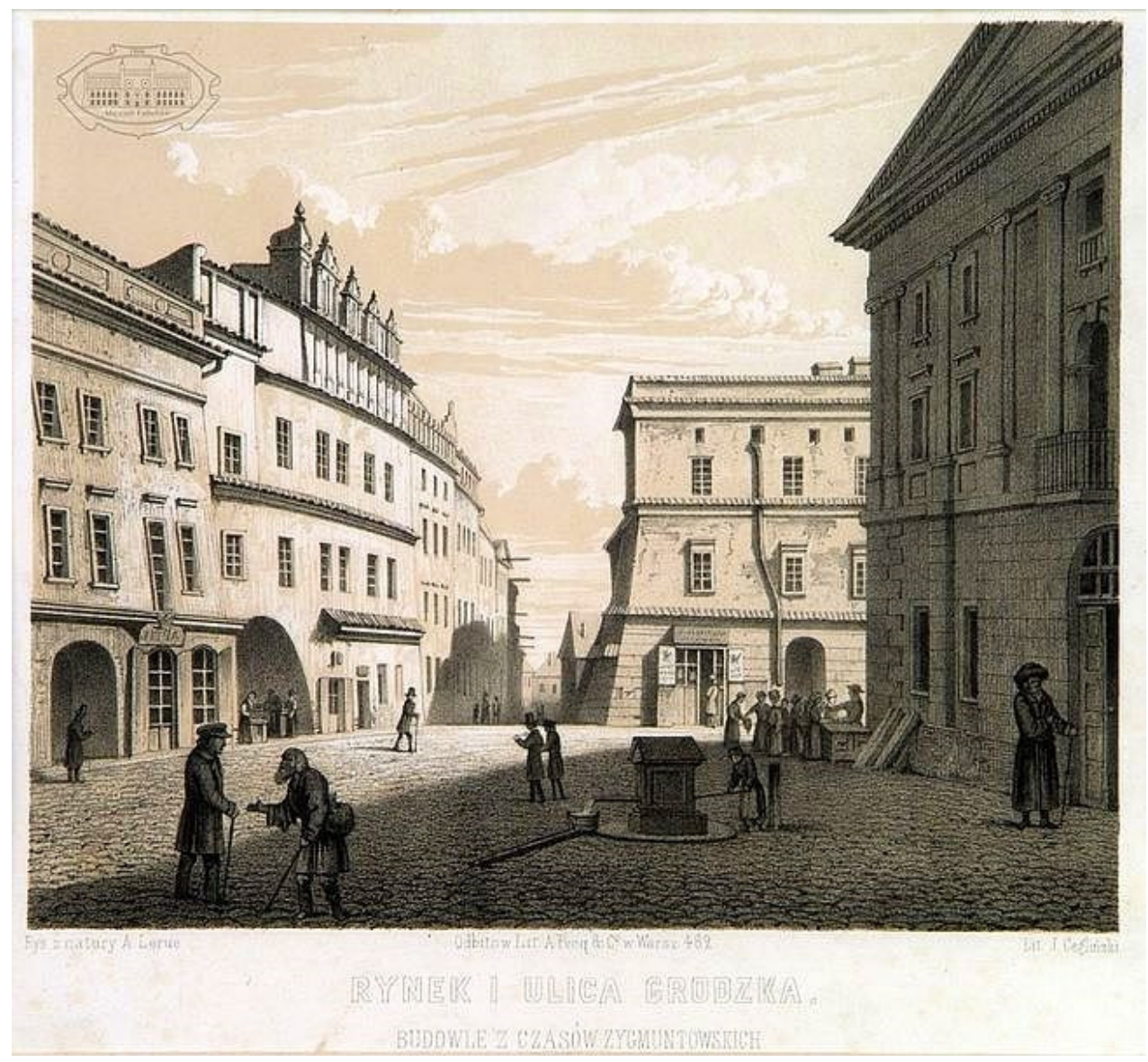

Ryc. 1. Staromiejski Rynek i ulica Grodzka według Adama Lerue (1852), repr. ze zbiorów Muzeum Lubelskiego w Lublinie.

Pod względem narodowościowym i wyznaniowym uległy w tym czasie pewnym zmianom proporcje między zamieszkującymi miasto dwiema dominującymi nacjami: chrześcijanami (Polakami) i starozakonnymi (Żydami). W 1830 r. chrześcijanie stanowili 49,5\%, Żydzi - 47,8\%, dwa lata później odpowiednio $48,2 \%$ i $55,1 \%$. Na początku lat 40 . odsetek chrześcijan wahał się od 39,6\% do 41,8\%, Żydów wzrósł do 58,2\%. W 1856 roku procentowy stosunek obu nacji wynosił $44,5 \%$ i $55,4 \%$ i na takim mniej więcej poziomie (z wahaniami na poziomie ok. $2 \%$ na rzecz Żydów) utrzymał się do wybuchu powstania styczniowego. Pozostałą część mieszkańców stanowili: niewielka, ale widoczna w życiu miasta społeczność ewangelicka, której przez wiele lat (1838-1884) przewodził światły pastor Karol Jonscher (w 1837 r. - 245 
osób, w 1847 r. - 252, w 1856 r. - 242, w przededniu powstania - 277) oraz marginalne, kilkudziesięcioosobowe skupiska wyznawców prawosławia (przeważnie wyższych urzędników, wojskowych, nauczycieli i duchownych) i grekokatolików ${ }^{20}$.

Tę zróżnicowaną pod względem pochodzenia i konfesji mozaikę uzupełniała obecność ludności niestałej. Rekrutowała się ona w znacznej mierze spośród włóczęgów, poszukujących zarobku małomiasteczkowych wyrobników, służących i chłopów z okolicznych wiosek, którzy współtworzyli dynamiczną społeczność „ludzi luźnych”, dalej z czeladzi rzemieślniczej i odbywających wędrówkę terminatorów, służby i uczniów gimnazjalnych. Odrębną grupę stanowił garnizon wojskowy, stacjonujący zrazu jedynie w koszarach świętokrzyskich za rogatką warszawską (obecnie gmach Katolickiego Uniwersytetu Lubelskiego). O jego składzie i obliczu decydowały rosyjskie jednostki piechoty, kawalerii i formacji kozackich wraz z przynależnymi doń komendami i komisjami wojskowymi. Garnizon liczący w 1844 r. 1147 żołnierzy, w dobie Wiosny Ludów osiągnął stan 2503 żołnierzy. W późniejszym okresie liczba wojskowych podlegała wprawdzie wahaniom in minus, niemniej w 1857 r. siłę jednostki ponownie wzmocniono i tendencja ta utrzymała się $\mathrm{w}$ burzliwych latach poprzedzających wybuch powstania styczniowego. W 1858 r. garnizon liczył 1999 żołnierzy, w 1861 r. - 3001, rok później 3029. W 1863 r. stacjonowało w Lublinie już

${ }^{20}$ SGKP, t. V, s. 421; S.Z. SIERPIŃSKI, Obraz miasta Lublina, s. IX; H. WIERCIEŃSKI, Opis statystyczny, s. 150; Pamiętnik Ignacego Baranowskiego, s. 26-28, 31; T. Mencel, Organizacja administracji, s. 55-56; W. ĆWIK, Miasta rzadowe małopolskiej części Królestwa Polskiego 18151866 (stan gospodarczo-społeczny”, „Rocznik Lubelski” 10 (1967), s. 237; B. MiKULEC, Aktywność gospodarcza ludności żydowskiej Lublina w latach 1815-1864, w: Żydzi w Lublinie, red. T. Radzik, Lublin 1995, s. 68-69; TENŻE, Aktywność gospodarcza i filantropijna ewangelików w Lublinie w XIX wieku, w: Ku Niepodległej. Ścieżki polskie i francuskie 1795-1918, red. M. Willaume, Lublin 2005, s. 126-127; R. KUwAŁEK, Społeczność żydowska w XIX i XX wieku, w: R. KuwAŁEK, W. WysoK, Jerozolima Królestwa Polskiego, Lublin 2001, s. 50; R. BENDER, Powstanie czy samorząd?, s. 70; T. RADZIK, Żyli z nami, w: Lublin $w$ dziejach, s. 263; W. ŚLADKOWSKI, W epoce zaborów, s. 59; J. CZerepińsKa, G. MiChalsKa, A. UlJasz, Ewangelicy lubelscy, w: Parafia ewangelicko-augsburska w Lublinie. Historia - tradycja - wspótczesność, Lublin 2007, s. 76; N. PRZESMYCKA, Lublin. Przeobrażenia urbanistyczne 1815-1939, Lublin 2012, s. 48. Wśród innych nacji mieszkających w Lublinie na wspomnienie zasługują Francuzi i Szwajcarzy. W okresie międzypowstaniowym przybyło do miasta, na dłuższy bądź krótszy czas, około 51 Francuzów. Wśród nich znajdowali się przede wszystkim poszukujący pracy w dobrych domach metrowie i guwernerzy oraz bony i guwernantki. Mniej było urzędników, prawników, lekarzy i artystów. W gronie Szwajcarów przeważały guwernantki i bony oraz przede wszystkim cukiernicy. Ci ostatni, wraz z rodzinami, tworzyli w 1839 r. dwudziestoosobową grupę, która po latach uległa uszczupleniu. Zob. A. KAPRoŃ, Francuzi $w$ dziewiętnastowiecznym Lublinie, Lublin 2003, passim; TENŻE, Szwajcarzy na Lubelszczyźnie w latach 1815-1914, Szczecin 2009, passim. 
4870 sołdatów, co stanowiło $25 \%$ ludności miasta. Generalnie rzecz biorąc, potencjał ludności niestałej był niemały - dość powiedzieć, że w $1860 \mathrm{r}$. ogół mieszkańców stolicy guberni liczył około 25000 osób ${ }^{21}$.

Rozpatrując powyższe dane w nieco szerszym kontekście, należy podkreślić, że w epoce międzypowstaniowej Lublin był największym miastem Królestwa leżącym po prawej stronie Wisły. Zostawiał on daleko w tyle pozostałe centra administracyjne Lubelszczyzny i Podlasia, na tle kraju zaś ustępował miejsca jedynie dwóm ośrodkom - deklasującej konkurencję Warszawie (w 1860 roku 158120 mieszkańców) i Łodzi, liczącej wówczas 26073 osoby $^{22}$. Dla wzrostu liczby mieszkańców podstawowe znaczenie miał, wspomniany wyżej, dopływ ludności z bliższego i dalszego sąsiedztwa, ale też osiedleńców spoza Lubelszczyzny, którzy szukali tu dogodnych warunków do życia czy szansy na zyskowną działalność handlową, rzemieślniczą lub przemysłową. $Z$ upływem lat rosła liczba osiadłej $\mathrm{w}$ mieście szlachty dziedzicznej i osobistej, różnych wytwórców, pracowników rękodzielni i przede wszystkim miejskiej biedoty. Rokrocznie przybywało do Lublina po kilkaset osób, najwięcej w 1846 r. - 1040, w 1858 r. - 876, cztery lata później - 852. Ogólnie rzecz biorąc, procesom demograficznym i w konsekwencji miastotwórczym i gospodarczo-rozwojowym sprzyjały pełnione przez Lublin funkcje w strukturach administracji wojewódzkiej (gubernialnej) i obwodowej (powiatowej) oraz w aparacie władz miejskich i urzędniczych. Miasto było poza tym siedzibą sądów i agend kredytowych (Dyrekcja Szczegółowa Towarzystwa Kredytowego Ziemskiego), ważnym węzłem komunikacyjnym i traktem pocztowym ${ }^{23}$. Odgrywało także istotną

\footnotetext{
${ }^{21}$ T. MenCEL, Organizacja administracji, s. 58, 60; TENŻE, Między powstaniami, s. 556; H. GAWARECKI, Stanistaw Krzesiński: „Dwa wrażenia..., czyli Lublin jakim byt w roku 1827 i jakim jest w roku 1877”, „Rocznik Lubelski” 1 (1958), s. 232; G. FigIEL, Miasto między powstaniami, s. 174; D. KociubA, Rozwój przestrzenny Lublina od średniowiecza do wspótczesności, w: Lublin. Historia, społeczeństwo, gospodarka, red. W. Janicki, Lublin 2018, s. 30.

${ }^{22}$ S. MıŁKowsKi, Opis Królestwa Polskiego pod względem geografii, statystyki i historii, Warszawa 1861, s. 21; H. WierCIEŃSKI, Opis statystyczny, s. 125-127; A. JELONEK, Ludność miast i osiedli typu miejskiego na ziemiach polskich od 1810 do 1960 r., Warszawa 1967, s. 18, 26, 28, 38, 41, 55; T. Mencel, Organizacja administracji..., s. 60; A. KopruKowniaK, Obraz miasteczek Lubelskich, s. 16; Historia Lublina w liczbach, oprac. A. Jakubowski, U. Bronisz, E. Łoś, Lublin 2018, s. 46.

${ }^{23} \mathrm{~W}$ następstwie przeprowadzonej w okresie konstytucyjnym przebudowy i regulacji biegnących przez miasto dróg i mostów ustabilizowano najważniejsze szlaki komunikacyjne i pocztowe. Z przedłużenia wytyczonej wówczas ulicy Nowej powstał trakt lubartowski (wiodący dalej do Terespola i Brześcia), który zastąpił dotychczasowy gościniec dyski koło Czwartku. Po usypaniu wysokiego nasypu prowadzącego od katedry w dół ku Bystrzycy oraz po wyburzeniu wypalonych zabudowań pojezuickich i zbudowaniu mostu wytrasowano ulicę Królewską i trakt zamojski. Dawną,
} 
rolę w dziedzinie życia religijnego katolików (stolica rzymskokatolickiej diecezji lubelskiej, sieć kilkudziesięciu kościołów i klasztorów), Żydów (8 synagog i kilkanaście domów modlitwy) i innych mniejszości: unitów skupionych przy parafialnej cerkwi greckokatolickiej p.w. Przemienienia Pańskiego przy ulicy Ruskiej, ewangelików posiadających własny zespół kościelny p.w. Świętej Trójcy przy Krakowskim Przedmieściu (wraz z Domem Schronienia i szkołą) i prawosławnych, którzy przejęli Kaplicę Grecką przy ulicy Zielonej i przebudowali kościół powizytkowski na cerkiew (obecnie siedziba Centrum Kultury przy ulicy Peowiaków). Nie mniejsze znaczenie miał Lublin na polu ruchu oświatowego. Najważniejsza rola przypadła tu męskiemu Gimnazjum Wojewódzkiemu (później Gubernialnemu), przekształconemu w 1862 r. w liceum (w latach 1842-1846 naukę pobierało w placówce rokrocznie około 320 uczniów, w roku szkolnym 1861/1862 573), 4-klasowej Szkole Realnej (1845), kilku pensjom dla dziewcząt oraz otwartej w 1860 r. Szkole Wyższej Żeńskiej, gdzie edukację rozpoczęło ponad 100 uczennic $^{24}$.

Pomimo postępującego wraz z upływem lat przyrostu liczby ludności oraz ugruntowywania wielofunkcyjnej roli miasta, Lublin pod względem

uciążliwą komunikacyjne drogę na Warszawę przez Wieniawę i Snopków zastąpił trakt warszawski. Powstał on z przedłużenia Krakowskiego Przedmieścia wzdłuż obecnych Alei Racławickich. Po zakończeniu robót wszystkie trakty zbiegały się na placu przed Bramą Krakowską. Pozostawiając na uboczu Stare Miasto, formowały one nowy układ urbanistyczny Lublina, którego centrum stało się Krakowskie Przedmieście. Wśród traktów pocztowych pierwszorzędną rolę odgrywały: warszawski - wiodący przez Markuszów, Kurów, Końskowolę i Puławy, wołyńsko-lwowski - zmierzający do Piask i Krasnegostawu i dalej rozwidlający się na Hrubieszów oraz na Zamość, Krynice i Tomaszów, gościniec krakowski - przecinający Bełżyce, Urzędów i Rachów, litewski - biegnący przez Lubartów. Zob. I. LuBOwIECKI, Statystyka województwa lubelskiego, Lublin 1824, s. 29-30; T. MENCEL, Lublin przedkapitalistyczny, s. 202; TENŻE, Organizacja administracji, s. 49; W. ŚLADKOWSKI, Wepoce zaborów, s. 28-29; TENŻE, Rozwój przestrzenny Lublina w XIX i XX stuleciu, w: Stare i nowe struktury spoleczne $w$ Polsce, t. IX: Przestrzeń antropogeniczna miasta Lublina. Waloryzacja, Wytwarzanie. Uzytkowanie, red. J. Styk, Lublin 2009, s. 64-65; N. PrZESMYCKA, Lublin. Przeobrażenia urbanistyczne, s. 55, 57.

${ }^{24}$ I. LUBOwIECKI, Statystyka województwa lubelskiego, s. 29-30; S. MıŁKOwSKI, Opis Królestwa Polskiego, s. 141; S.Z. SIERPIŃSKI, Obraz miasta Lublina, s. 54,178; M.A.R., Ilustrowany przewodnik po Lublinie, s. 171-174; H. WIERCIEŃSKI, Opis statystyczny, s. 173-175, 178; Pamiętnik zjazdu bylych wychowańców Szkót Lubelskich, Lublin 1926, s. 24; J. DOBRZAŃSKI, Życie umystowe, szkolnictwo $i$ oświata w I połowie XIX wieku, w: Dzieje Lublina, s. 249-251; T. MENCEL, Organizacja administracji, s. 58; T. RADZIK, Żyli z nami, s. 246-247, 256; W. ŚLADKOWSKI, W epoce zaborów, s. 57, 69-71; J. CZEREPIŃSKA, G. MichalSKA, J. STUDZIŃSKI, Zespót kościoła Świętej Trójcy w Lublinie, w: Parafia ewangelicko-augsburska, s. 41-58; I. SADURSKI, Regulaminy $i$ wymogi obowiąujące uczniów Gimnazjum Lubelskiego w dobie międzypowstaniowej, „Rocznik Lubelski" 43 (2017), s. 71; Historia Lublina, s. 61. 
przestrzennym rozwijał się nieśpiesznie. Włodarze stolicy województwa, odwołując się do przedrozbiorowych przywilejów lokacyjnych, w latach 1819-1822 ustabilizowali granice miasta i później nie podlegały już one znaczniejszym korektom. Zamknięty w ten sposób obszar został ograniczony rogatkami: warszawską za okopami miejskimi u wylotu Krakowskiego Przedmieścia i traktu na Warszawę, lubartowską - przy moście na Czechówce u wylotu ulicy Lubartowskiej, zamojską (zwaną też piasecką lub bychawską) z przedłużenia traktu na Zamość przy moście na Bystrzycy i łęczyńską na Kalinowszczyźnie przy drugiej przeprawie przez rzekę. Ogólny obszar własności miejskiej wraz z przedmieściami, przynależnymi folwarkami i innymi nomenklaturami (lasami i pojedynczymi gruntami poza okręgiem administracyjnym Lublina) wynosił w 1824 r. 124 włóki, czyli około 3720 mórg. W 1845 r., po uwzględnieniu nowych, bardziej szczegółowych pomiarów, rozległość ta przekroczyła 128 włók (3840 mórg), z czego tylko 21 włók znajdowało się pod zabudowaniami miejskimi i przylegającymi doń sadami. Pozostałą część stanowiły: łąki i pastwiska (90 włók), ogrody i grunty orne (12 włók), nieużytki i inne drobne obszary oraz lasy, drogi i rzeki ${ }^{25}$. Na początku lat 60 . całkowita powierzchnia Lublina wynosiła 1805 mórg, przy czym samo miasto, liczone bez przedmieść i innych przynależności, zajmowało przestrzeń 670 mórg 225 prętów ${ }^{26}$.

Ówczesny Lublin, graniczący od wschodu z Jakubowicami i wsią prywatną Tatary, od strony zachodniej z Konopnicą, od południa z Wrotkowem i od północy z Wieniawą, Czechówką Górną i Dysem, dzielił się na dwa cyrkuły. Cyrkuł I stanowiło tzw. miasto chrześcijańskie, które obejmowało Stare Miasto i rejon Krakowskiego Przedmieścia wraz z przylegającymi ulicami - Królewską, Zamojską i traktem lubartowskim. Cyrkuł II, tzw.

\footnotetext{
${ }^{25}$ T. Mencel, Organizacja administracji, s. 47-50; TENŻE, Lublin przedkapitalistyczny, s. 202; J. MAZURKIEWICZ, Wtasność $i$ zmiany $w$ stosunkach wlasnościowych $w$ Lublinie $w$ latach sześćdziesiatych XIX stulecia, „Rocznik Lubelski” 6 (1963), s. 170; W. ŚLADKOWSKI, W epoce zaborów, s. 25, 27; TENŻE, Rozwój przestrzenny, s. 64; N. PRZESMYCKA, Lublin. Przeobrażenia urbanistyczne, s. 51; G. Figiel, Miasto między powstaniami, s. 168. W świetle przedstawionej powyżej struktury własności miejskiej zajęcia rolnicze lublinian, a zwłaszcza mieszkańców przedmieść, stanowiły istotną część ich codziennej aktywności. Wiadomo, że u schyłku lat trzydziestych zajmowano się uprawą czterech zbóż (jęczmienia, owsa, pszenicy, żyta), sadzono sporo ziemniaków, mniej grochu i tatarki. Hodowano poza tym woły i konie, krowy, świnie, kozy i owce (proste i merynosy). Po latach, bo w 1865 r., a więc już po odpadnięciu od Lublina Bronowic, grunty rolnicze znajdujące się w obrębie terenów miejskich liczyły jeszcze 1097 mórg 280 prętów (w tym 1049 mórg 83 pręty pod rolami i 48 mórg 197 prętów pod pastwiskami i łąkami). Zob. S.Z. SIERPIŃSKI, Obraz miasta Lublina, s. 125-126; J. MAZURKIEWICZ, Własność i zmiany, s. 170; W. ĆwIK, Miasta rządowe, s. 232.

${ }^{26}$ SGKP, t. V, s. 421; A. KIEREK, Rozwój Lublina w latach 1864-1914, w: Dzieje Lublina, s. 259.
} 
miasto żydowskie, ogarniał Podzamcze z przedmieściami: Czwartkiem (przedłużeniem tegoż był folwark skarbowy Wiktoryn-Bazylianówka), Kalinowszczyzną (liczoną z Białkowską Górą uzależnioną od prywatnego właściciela i Słomianym Rynkiem), Piaskami (zwanymi dawniej Kazimierzem) i Sierakowszczyzną. Ta ostatnia była nomenklaturą pojezuicką (tzw. Funduszu Edukacyjnego) i znajdowała się pod nadzorem skarbowym. Do miasta należało też Czechowskie Przedmieście z Lemszczyzną oraz folwark miejski Ponikwoda, oddany w dzierżawę wieczystą Michałowskiemu. Większość wymienionych wyżej terenów stanowiły więc grunty pojurydyczne. $\mathrm{Na}$ południu, już poza granicami Lublina, pozostawał drugi z folwarków - Bronowice. Wypuszczony przez miasto w arendę wieczystą Antoniemu Makarewiczowi (1822) został w 1855 r. przejęty przez Magistrat pod własną administrację. U schyłku lat 50. część tych ziem, tzw. grunty powłościańskie wraz z wapiennikiem, czyli pozostałością kopalni kamienia budulcowego, wydzierżawił, a później nabył przemysłowiec Michał Kośmiński. Od jego nazwiska wzięła się późniejsza nazwa dzielnicy - Kośminek. W sąsiedztwie południowo-zachodnich granic miasta znajdował się folwark skarbowy Rury Brygidkowskie arendowany przez Lingenaów z Dąbrowicy. Nomenklatura ta sąsiadowała z cmentarzem Rurskim „Pod Lipkami”, cegielnią miejską, terenem zajętym przez wojsko i majoratem „Lublin”. Majorat, złożony początkowo ze wsi zarobnych i folwarków Brzostówka, Chmiel, Dziesiąta, Świdnik Mały, Wrotków i Zemborzyce oraz młyna rządowego (tzw. Papierni) w prywatnej wsi Tatary, stanowił od 1835 r. donację generała adiutanta hr. Fiodora (Teodora) Rüdigiera ${ }^{27}$. Odrębny charakter zachowała wreszcie zamieszkała w większości przez Żydów Wieniawa - niegdysiejsza jurydyka, później miasto prywatne, które w 1826 r., wraz z Czechówką Dolną, stało się własnością rządową ${ }^{28}$.

\footnotetext{
${ }^{27}$ Po kilku latach odpadła od majoratu papiernia oraz wsie i folwarki Brzostówka, Chmiel i Świdnik Mały, przybyły natomiast dwa duże klucze Czerniejów i Skrzynice, znajdujące się już, rzecz jasna, daleko poza przedmieściami. Szerzej zob. S. PIĄTKOWsKi, Modernizator czy ciemiężca? Generał Teodor Rüdigier jako donatariusz lubelski, w: Studia nad ziemiaństwem w XIX i XX wieku, red. A. Koprukowniak i Z. Gołębiowska, Lublin 2008, s. 113-117.

${ }^{28}$ S.Z. SIERPIŃSKI, Obraz miasta Lublina, s. 6, 27-35; M.A.R., Ilustrowany przewodnik po Lublinie, s. 215; B. Mikulec, Kośmiński Michat, w: Stownik Biograficzny Miasta Lublina (dalej: SBML), t. III, red. T. Radzik, A.A. Witusik, J. Ziółek, Lublin 2009, s. 158; J. WiLlaume, Z dziejów wsi lubelskiej przed uwtaszczeniem, s. 88; T. MENCEL, Organizacja administracji, s. 50, 53; M. BUCZYŃSKI, Nazwy dzielnic i przedmieść Lublina, „Rocznik Lubelski” 5 (1962), s. 263; J. MAZURKIEWICZ, Własność i zmiany, s. 171-173, 179; Z. STANKIEwICZ, Spór o Rury Brygidkowskie. Przyczynek do dziejów rozwoju terytorialnego Lublina w XIX wieku, „Rocznik Lubelski” 13 (1970), s. 102-107; W. Wiтkowski, Podlubelska Wieniawa, „Rocznik Lubelski” 14 (1971), s. 156-161;
} 
Podzielony na cyrkuły Lublin stanowił w istocie dwa odrębne światy. Miasto chrześcijańskie, zgodnie z prawem zamknięte do czasu reform margrabiego Aleksandra Wielopolskiego przed Żydami (ukaz carski o równouprawnieniu ludności mojżeszowej został ogłoszony 24 maja/5 czerwca $1862 \mathrm{r}^{29}$ ), było na pozór schludne, choć codzienne utrzymanie porządku i czystości pozostawiało wiele do życzenia. Miało ono brukowane ulice, przy których stały piętrowe kamienice, kościoły i klasztory. Uwagę przechodniów zwracały pełniące różne funkcje pałace i place. Wśród tych ostatnich wyróżniały się: wzorowany na placu Saskim w Warszawie plac Litewski wraz z przylegającym Polem Marsowym i plac Królewski (Katedralny) przy katedrze. W śródmieściu miały swoją siedzibę urzędy wojewódzkie, a później gubernialne, tu rezydowały władze miejskie i sądy, tu także mieściły się szkoły i inne instytucje. Miasto żydowskie, tworzące osobną gminę podlegającą dozorowi bożniczemu, było z kolei przeludnione i zaniedbane. Łącznik z cyrkułem I stanowiły ulice: Grodzka, Dominikańska i Złota. Granicę obu dzielnic wyznaczała Brama Grodzka oraz znajdujące się poniżej, na Podwalu, poklasztorne zabudowania wraz ze zniesionym szpitalem św. Łazarza i kościołem św. Wojciecha. Cały kompleks stał się w połowie lat 30. własnością Stanisława Lingenaua, który w budynku poduchownym urządził kamienicę czynszową zamieszkiwaną w większości przez Żydów. W kościele umieszczono $\mathrm{z}$ czasem magazyn. W mieście żydowskim, poza starozakonnymi, mieszkali chrześcijańscy wyrobnicy, podupadli rzemieślnicy i przekupnie, wreszcie „ludzie luźni”, którzy powiększali odsetek tamtejszej biedoty. Główną arterię cyrkułu stanowiła ulica Szeroka - dość porządnie zabudowana i wybrukowana, gdzie koncentrował się handel uliczny. Pozostałe znaczniejsze ulice: Kowalska, Nadstawna i Ruska były nieutwardzone,

M. Gmiter, B. Kotowski, K. KuCharska, B. LASKowsKa, L. PopeK, Cmentarz rzymskokatolicki przy ul. Lipowej w Lublinie, Lublin 1990, s. 11-13; N. PRZESMYCKA, Lublin. Przeobrażenia urbanistyczne, s. 50; R. ŁozIŃSKI, Zemborzyce. Szkice z dziejów wsi i dzielnicy miasta, Lublin 2005, s. 106; H. DanczowsKa, Dziesiąta. Dzieje dzielnicy Lublina, Lublin 2007, s. 15; G. FigIEL, Miasto między powstaniami, s. 168; W. ŚLADKOWSKI, W Księstwie Warszawskim i w Królestwie Polskim 18091830, w: Lublin. 700 lat, s. 129-130; H. GMITEREK, Lublin jurydyk i Trybunalu Koronnego, w: Lublin. 700 lat, s. 86-88; J. STUDZIŃSKI, Dzielnice przyległe do Śródmieścia, w: Lublin. Przewodnik, red. P. Kawałko, Z. Nestorowicz, Lublin 2012, s. 349; A. PRZEGALIŃSKI, W źródtach zapisane. Dzieje Dąbrowicy i Plouszowic w pierwszej połowie XIX wieku w świetle dokumentów hipotecznych i notarialnych, w: Z dziejów Jastkowa i okolic. Studia i materiaty, t. V, red. C. Taracha, Lublin 2017, s. 57.

${ }_{29}$ J. KirsZROT, Prawa Żydów w Królestwie Polskim. Zarys historyczny, Warszawa 1917, s. 18; A. PALIMĄKA, Zmiany w sytuacji prawnej Żydów na ziemiach zaboru rosyjskiego w pierwszej potowie XIX wieku (do 1862 r.), „Śląskie Studia Historyczno-Teologiczne” 2 (2009), z. 1, s. 120, 131132; R. SzuCHTA, 1000 lat historii Żydów polskich. Podróż przez wieki, Warszawa 2015, s. 111. 


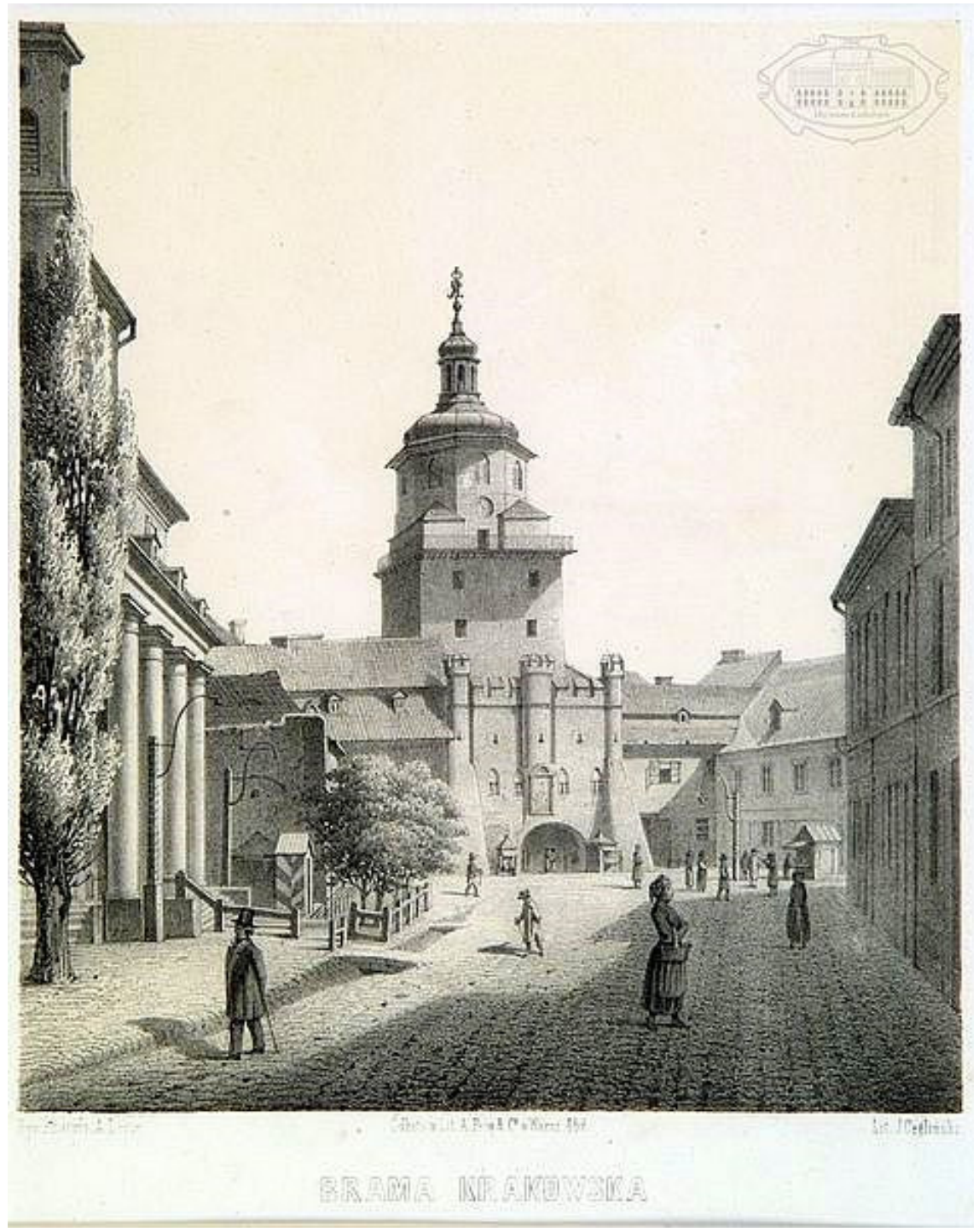

Ryc. 2. Widok Bramy Krakowskiej od strony Krakowskiego Przedmieścia według A. Lerue (1852), repr. ze zbiorów Muzeum Lubelskiego w Lublinie.

ciasne i brudne. Otaczała je gęsta, wzniesiona bez planu, drewniana zabudowa, która sąsiadowała z wiejskimi chałupami i walącymi się lepiankami. $\mathrm{Na}$ ich tle wyróżniała się najważniejsza z żydowskich świątyń - murowana, piętrowa Wielka Synagoga (Synagoga Maharszala) przy ulicy Jatecznej z dobudowaną do jednej ze ścian mniejszą bożnicą Maharama. W obrębie cyrkułu znajdowały się także: synagoga Saula Wahla, nazywana Synagogą 
Gońców-kuśnierzy (Podzamcze), Kotler-szul pozostająca pod opieką cechu kotlarzy, Parnes, bożnica de Chassidim stanowiąca centrum życia chasydzkiego (wszystkie trzy przy ulicy Szerokiej) oraz murowana synagoga na Kalinowszczyźnie (ulica Towarowa) i drewniana na Piaskach. Na wygląd ogólny budynków i stan sanitarny cyrkułu wpływał nizinny i podmokły teren dzielnicy, którą okresowo zalewały wody z Bystrzycy i Czechówki oraz nieczystości z położonych wyżej Starego Miasta i Czwartku. Wobec braku śmietników i przydomowych podwórzy śmieci i resztki żywności wyrzucano wprost na ulice. Wszystko to razem sprzyjało pożarom, chorobom epidemicznym i w konsekwencji dużej śmiertelności. Stanowiło też kontrast $\mathrm{z}$ miastem zamkniętym granicami cyrkułu pierwszego ${ }^{30}$.

Ten brak zainteresowania Urzędu Municypalnego (od 1842 roku Magistratu) dzielnicą żydowską rozciągał się także na przedmieścia, które pozbawione dochodów z propinacji, jarmarków i targów traciły swój rzemieślniczo-handlowy charakter na rzecz rolniczych zajęć mieszkańców. Peryferia, wobec braku urządzeń miejskich (bitych dróg, bruków, studni i oświetlenia ulicznego), powiększały dystans do „chrześcijańskiego” Lublina i nie wykazywały w istocie żadnych tendencji rozwojowych. Na ich tle nie wyróżniała się też specjalnie Wieniawa - przeludnione miasteczko (w 1856 r. 1104 osoby) na uboczu traktu warszawskiego, tak jak przedmieścia drewniane, „spróchniałe starością,31, ubogie i brudne, gdzie cherlawe rzemiosło przenikało się z drobnym handlem, funkcję unifikującą zaś dla dominującej społeczności żydowskiej pełnił rabinat, murowana synagoga, drewniany dom modlitwy i cheder. Wraz ze wzrostem liczby mieszkańców Lublina podejmowano wprawdzie próby wcielenia do miasta kilku przyległych realności, tj. Bronowic, Rur Brygidkowskich i Wieniawy, ale wysiłki te nie dały żadnych rezultatów i przedmieścia pozostawały na marginesie procesów miastotwórczych. W podobny sposób rozwój krańców Lublina hamowała wspomniana

\footnotetext{
${ }^{30}$ Katalog Zasobów Kulturowych Miasta Lublina (dalej: KZKML), oprac. M. Stasiak, Lublin 1999, poz. 450; S.Z. SIERPIŃSKI, Obraz miasta Lublina, s. 22-23, 26-27; M.A.R., Ilustrowany przewodnik po Lublinie, s. 52, 229; H. GAWARECKI, O dawnym Lublinie, s. 73-75; TENŻE, Stanisław Krzesiński, s. 238; TENŻE, Porównawczy opis Lublina z lat 1822 i 1899 Seweryna Liniewskiego, „Studia i Materiały Lubelskie”. Historia Sztuki 1-2 (1963), s. 261, 269; T. MENCEL, Organizacja administracji, s. 51-52; TENŻE, Lublin w okresie, s. 133-134, 136; M. BAŁABAN, Żydowskie miasto w Lublinie, Lublin 1991, s. 109-112; W. ŚLADKOWSKI, W epoce zaborów, s. 25; B. MiKULEC, Kośmiński Michat, s. 69; J. SKARBEK, Żydzi Lublina podczas powstania, s. 131; M. DuBrowsKA, Od „Jerozolimy Królestwa Polskiego” do miejsca pamięci - żydowski Lublin, „Studia Europaea Gnesnensia" 1-2 (2010), s. 376; R. KuWAŁEK, Lubelskie synagogi, w: R. KuWAŁEK, W. WYsoK, Jerozolima Królestwa Polskiego, s. 34-38; A. PRZEGALIŃSKI, W źródłach zapisane, s. 59.

${ }^{31}$ S.Z. SIERPIŃSKI, Obraz miasta Lublina, s. 12.
} 
wyżej donacja F. Rüdigiera, która otaczała miasto pierścieniem od wschodu, zachodu i od południa ${ }^{32}$.

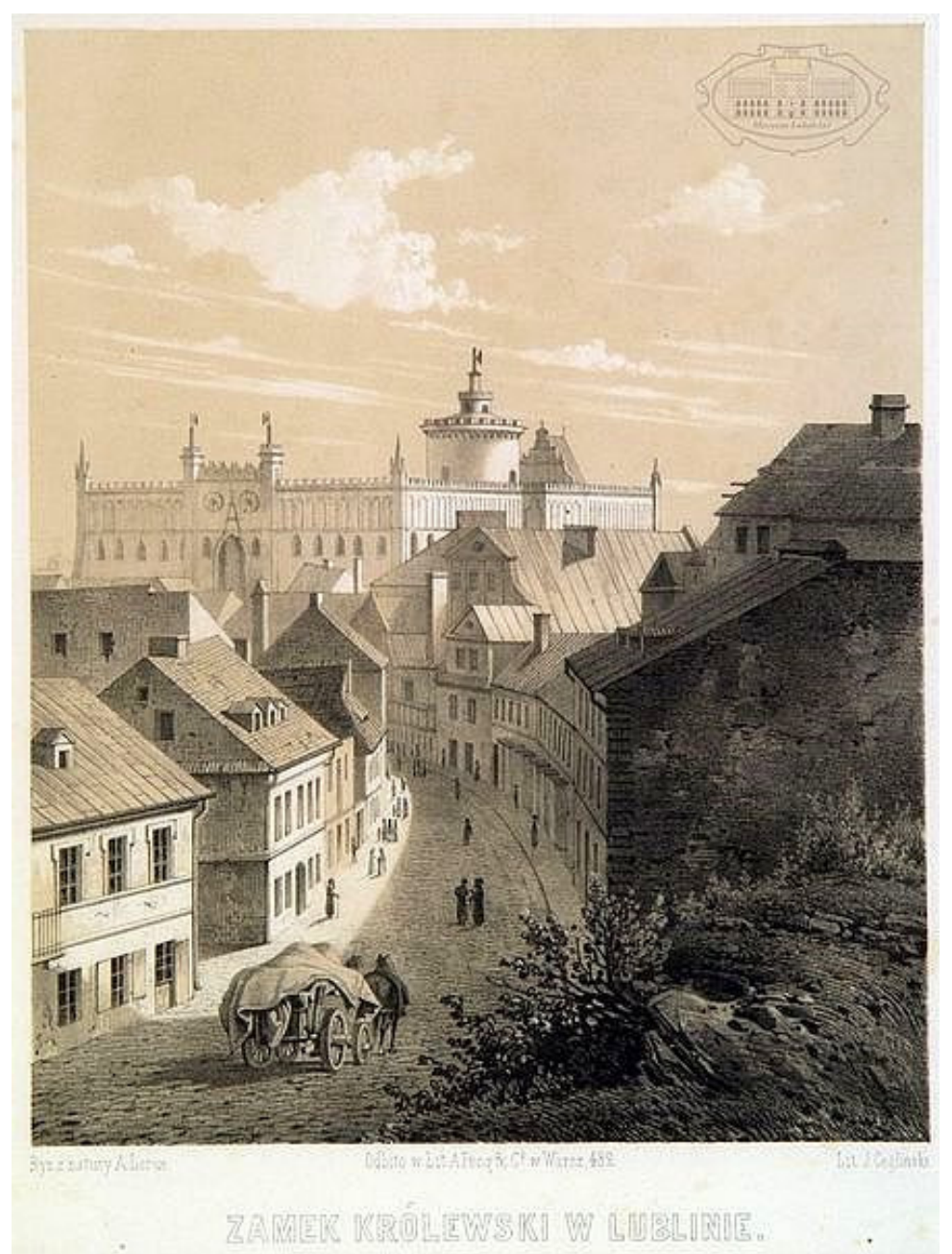

Ryc. 3. Widok na Zamek Królewski od strony Bramy Grodzkiej wedug A. Lerue (1852), repr. ze zbiorów Muzeum Lubelskiego w Lublinie.

${ }^{32}$ Raport Urzędu Municypalnego, s. 128; H. WIERCIEŃSKI, Opis statystyczny, s. 128; M.A.R., Ilustrowany przewodnik po Lublinie, s. 53; T. MENCEL, Organizacja administracji, s. 52-54; W. WitKowsKi, Podlubelska Wieniawa, s. 160; Z. STANKIEWICZ, Spór o Rury Brygidkowskie, s. 104105, 107-108; N. PrzeSMYcKa, Lublin. Przeobrażenia urbanistyczne, s. 50; A. KiereK, Rozwój przestrzenny i stan urządzeń komunalnych m. Lublina w latach 1870-1915, „Rocznik Lubelski” 14 (1971), s. 175; A. KopruKowniaK, Obraz miasteczek Lubelskich, s. 14-15; R. KuWaŁeK, Spoleczność żydowska na Wieniawie w XIX i XX wieku, w: Żydzi w Lublinie, t. II, s. 174-177. 


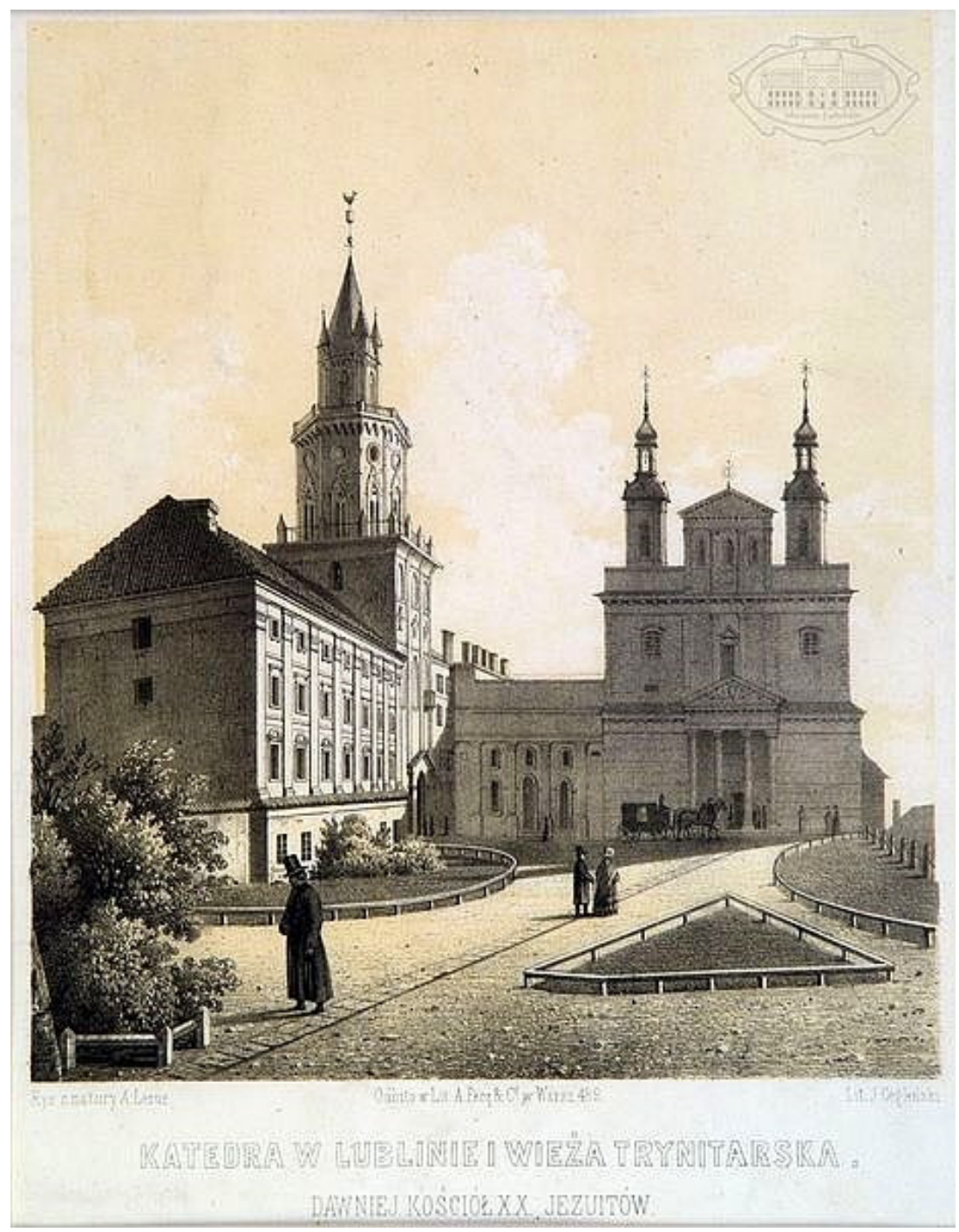

Ryc. 4. Widok na plac Katedralny, katedrę i Wieżę Trynitarską według A. Lerue (1852), repr. ze zbiorów Muzeum Lubelskiego w Lublinie.

Jak wyżej zauważono, kondycja gospodarczo-finansowa Lublina w pierwszych latach po upadku zrywu powstańczego przedstawiała się niekorzystnie. W następstwie wzmożonych wydatków przedlistopadowych, związanych z melioracją, później zmagań wojennych i zniszczeń, wreszcie w wyniku działalności skorumpowanych prezydentów i konieczności spłaty przedwojennego zadłużenia finanse miasta uległy destabilizacji. 
Podstawą dochodów stałych było w epoce czopowe (od sprzedawanych trunków) w wysokości 40\% ogółu wpływów i kopytkowe (16\%). Tak zwane celbudy, czyli budynki strażniczo-fiskalne, znajdowały się przy ulicy Ruskiej oraz przy rogatkach: bychawskiej, lubartowskiej, tatarskiej, rurskiej i warszawskiej. Niemałe fundusze czerpano też z czynszów ze starego ratusza (dawnego Trybunału Koronnego), zajętego przez sądy cywilne i pokoju, Zwierzchność Hipoteczną i podlegających jej rejentów, dalej ze szlachtuza, czyli rzeźni miejskiej w cyrkule II (nad Czechówką, u zbiegu Podzamcza i ulicy Jatecznej) oraz z cegielni na Rurach Brygidkowskich, dzierżawionej przez Żydów. Tę ostatnią, zniszczoną w czasie powstania, uruchomiono ponownie w latach 1833-1834. Pewne profity uzyskiwano również z tytułu wypuszczonych w dzierżawę Bronowic i Ponikwody, choć pierwszy z folwarków, doszczętnie - jak pamiętamy - zrujnowany, wymagał przede wszystkim znacznych nakładów finansowych, oraz $\mathrm{z}$ oddanego $\mathrm{w}$ arendę czasową ogrodu pod Wieniawą ${ }^{33}$.

$\mathrm{Na}$ wpływy niestałe składały się opłaty z tytułu konsensowego od szynków, z kanonu oraz z płatności wnoszonych przez procederzystów, czyli przedsiębiorców zarobkujących $\mathrm{w}$ mieście. Podobny charakter miały dochody „rozmaite”, pochodzące na ogół z opłat z balów, publicznych redut i reunionów. W budżecie miasta stanowiły one wartość znikomą ${ }^{34}$.

Wśród wydatków, poza pensjami dla urzędników miejskich (ok. 50\% budżetu), poważną część (10\%) stanowiły kwoty związane z utrzymaniem i konserwacją budynków należących do miasta, zachowaniem czystości i porządku oraz subsydiowaniem szpitalnictwa i oświaty. Niemałe sumy oddawano też do dyspozycji Komisji Rządowej Spraw Wewnętrznych i Komisji Wojewódzkiej (20-30\%). Szkodliwa dla interesów Lublina była przy tym zależność finansowa od władz administracyjnych, które przez system zaliczek (tzw. forszusów) dezorganizowały jego gospodarkę i uszczuplały finanse ${ }^{35}$.

Podejmowane przez miasto i mieszkańców prace, realizowane tuż po upadku powstania, wiązały się przede wszystkim z odbudową budynków publicznych i prywatnych. W ciągu kilku lat poddano restauracji całkowitej lub częściowej kilkanaście kamienic, kontynuowano też zainicjowany wcześniej proces znoszenia dachów słomianych i kominów sztagowych (słu-

\footnotetext{
${ }^{33}$ Raport Urzędu Municypalnego, s. 128-129; M.A.R., Ilustrowany przewodnik po Lublinie, s. 184; T. MEnCEL, Lublin przedkapitalistyczny, s. 208; A. KIEREK, Przemiany gospodarcze w Lublinie w latach 1795-1864, w: Dzieje Lublina, s. 224.

${ }_{34}$ T. MENCEL, Lublin przedkapitalistyczny, s. 208; TENŻE, Organizacja i działalność, s. 94.

35 T. MENCEL, Lublin przedkapitalistyczny, s. 208-209; TENŻE, Organizacja i działalność, s. 94; W. ŚladKOWSKI, W epoce zaborów, s. 56.
} 
powych, połączonych szponami i łatami oplecionymi słomą i dwustronną warstwą gliny). W 1832 r. ukończono rozpoczęty w okresie konstytucyjnym gruntowny remont katedry (dawnego kościoła pojezuickiego), przy której znalazła swe miejsce kapituła. Do końca 1833 r. odbudowano kościół i klasztor Augustianów, odnowiono też zabudowania probostwa św. Mikołaja na Czwartku ${ }^{36}$.

Kondycja finansowa Lublina zaczęła poprawiać się od połowy lat trzydziestych, co wiązało się z powolnym, ale systematycznym wzrostem dochodów budżetowych. W 1836 r. stan kasy miejskiej zamknął się sumą 129937 zł, rok później wpływy osiągnęły już 140347 zł. W 1843 r. dochody wyniosły 144720 zł (24 120 rb.), w 1850 r. - 26945 rb., dziesięć lat później - $33164 \mathrm{rb}$. Aktywa te byłyby wyższe, gdyby podatki i inne opłaty miejskie spływały na bieżąco. Pobierano jej jednak nieregularnie, co powodowało okresowe niedobory. O skali zjawiska świadczy fakt, że w $1861 \mathrm{r}$. zaległości podatkowe wynosiły ponad $20837 \mathrm{rb}$., rok później - $21008 \mathrm{rb} .{ }^{37}$ !

Rosnące kapitały pozwoliły na rozpoczęcie bądź kontynuowanie prac przerwanych przez powstanie, których koncept zawarto $\mathrm{w}$ opracowanym w 1837 r. dziesięcioletnim planie regulacyjnym. Sukcesywnie więc brukowano lub ponownie utwardzano śródmiejskie ulice (w tym Królewską, Nową, Poczętkowską, Świętoduską i Zieloną, w cyrkule II Ruską i Jateczną), do lepszego stanu doprowadzono szosy dojazdowe, odbudowano obydwa mosty na Bystrzycy. Do przełomu lat 30. i 40. oświetlono miasto ponad dwudziestoma nowymi latarniami rewerberowymi (olejnymi z lusterkiem) ${ }^{38}$, postawiono również kilkanaście nowych studni, a część pozostałych osłonięto ozdobnymi kolumnami. Poza tym zajęto się przebudową i oczyszczeniem śródmiejskich kanałów ściekowych, usypano groble dla zapobieżenia wiosennym wylewom rzek, konsekwentnie rozbierano zabudowę grożącą zawaleniem. W latach 1846-1852 zlikwidowano w ten sposób staromiejski kościół farny p.w. św. Michała oraz Bramę Świętoduską z zabudowaniami dawnego

\footnotetext{
${ }^{36}$ KZKML, poz. 456; Raport Urzędu Municypalnego, s. 131; S.Z. SIERPIŃSKI, Obraz miasta Lublina, s. 50, 52; W.K. ZIELIŃSKI, Monografia Lublina, Lublin 1878, s. 180; M.A.R., Ilustrowany przewodnik po Lublinie, s. 57-58; W. ŚLADKOWSKI, W epoce zaborów, s. 39.

${ }^{37}$ T. MENCEL, Lublin przedkapitalistyczny, s. 208; TENŻE, Lublin w okresie walk, s. 133; TENŻE, Organizacja i działalność, s. 94, 101; W. ŚLADKOwsKI, $W$ epoce zaborów, s. 56. Dla porównania dochody gminy żydowskiej, pochodzące w połowie ze składek mieszkańców, a w dalszej części z dzierżaw budynków i placów gminnych oraz z łaźni i jatek, wynosiły w 1831 r. 897 rb., dziesięć lat później - 2333 rb., w 1850 r. - 4724 rb., w 1856 r. -8503 rb., w 1861 r. - 4818 rb. Zob. T. MENCEL, Lublin w okresie, s. 137.

${ }^{38} \mathrm{~W}$ epoce konstytucyjnej postawiono w Lublinie 132 latarnie łojowe, zamienione następnie na rewerberowe. Zob. W. ŚLADKOWSKI, W epoce zaborów, s. 32.
} 
przytułku i szpitala przy kościele Świętego Ducha (ostatnie prace prowadzono w 1858 r.). W 1860 r. rozebrano staromiejską Bramę Rybną. Odnowiono też i pomalowano szereg kamienic, gruntownej restauracji poddano wreszcie staromiejski ratusz i kilka znaczniejszych zespołów sakralnych ${ }^{39}$.

W 1837 r. z wydatną pomocą inżyniera gubernialnego Feliksa Bieczyńskiego zaczęto urządzać Ogród Miejski (nazwany później Saskim) przy rogatce warszawskiej, na gruntach podominikańskich. Na obszernej parceli między koszarami świętokrzyskimi a Wieniawą powstał angielski park krajobrazowy malowniczo położony „wśród wzgórz, z pięknymi na miasto, las, chaty, ruiny i stawek czechowski widokami" ${ }^{40}$. W $1841 \mathrm{r}$. za ogrodem wybudowano drogę bitą, która połączyła Wieniawę z traktem warszawskim (obecna ulica Długosza) ${ }^{41}$.

\footnotetext{
${ }^{39}$ Staraniem S. Lingenaua wyremontowano zabudowania po skasowanym zakonie karmelitanek-poczętek przy ulicy Poczętkowskiej. Do nowej siedziby translokowano w 1835 r. z Podwala wspomniany wyżej przyklasztorny szpital św. Łazarza prowadzony przez siostry miłosierdzia. W latach 1836-1838 odnowiono klasztor i kościół pobrygidkowski przy ulicy Namiestnikowskiej, gdzie już w 1835 r. znalazły swą siedzibę lubelskie Wizytki. Renowacji poddano również gmachy pokarmelickie na Przedmieściu Czechowskim, które wraz ze szpitalem zostały objęte przez bonifratrów w 1839 r. Lepszych dni doczekała świątynia unicka przy ulicy Ruskiej odnowiona w 1837 r. Na koniec w latach 1850-1860 wyremontowano zespół klasztorny Bernardynów przy ulicy Dolnej Panny Marii. Z kolei umacnianiu wpływów religii panującej służyło (wspomniane powyżej) przeprowadzenie robót naprawczych przy dawnej Kaplicy Greckiej przy ulicy Zielonej (1833) oraz dokonana w latach 1836-1839 roku przebudowa kościoła powizytkowskiego na cerkiew garnizonową. Wespół z lazaretem i koszarami, które umieszczono w tamtejszych zabudowaniach poklasztornych, cerkiew tworzyła widoczny przyczółek prawosławia, a wraz z koszarami świętokrzyskimi, które także odrestaurowano, mocne oparcie dla wojska niemal w centrum miasta. Zob. KZKML, poz. 453, 458, 459, 465; 471; S.Z. SIERPIŃSKI, Obraz miasta Lublina, s. 49, 53-54, 60, 65, 181; W.K. ZIELIŃSKI, Monografia Lublina, s. 180-181; TENŻE, Opis Lublina jako przewodnik dla zwiedzajacych miasto i jego okolice, Lublin 1876, s. 40, 45, 54; M.A.R., Ilustrowany przewodnik po Lublinie, s. 157; 170-171; Pamiętnik Ignacego Baranowskiego, s. 16-17; A. WADOWSKI, Kościoły lubelskie, Kraków 1907, s. 199-203, 481-483; H. GAWARECKI, Cz. GAWDZIK, Lublin, Warszawa 1959, s. 67; T. MENCEL, Lublin przedkapitalistyczny, s. 209; W. ŚLADKOWSKI, W epoce zaborów, s. 56-58; Z przeszłości kulturowej Lubelszczyzny. Inwentarz topograficzno-rzeczowy zabytków województwa lubelskiego, oprac. I. Rolska-Boruch, Lublin 2002, s. 24; N. PRZESMYCKA, Lublin. Przeobrażenia urbanistyczne, s. 64; A. PRZEGALIŃSKI, $W$ źródtach zapisane, s. 59.

${ }^{40}$ S.Z. SIERPIŃSKI, Obraz miasta Lublina, s. 146.

${ }^{41}$ W.K. ZIELIŃSKI, Monografia, s. 181; M.A.R., Ilustrowany przewodnik po Lublinie, s. 230; J. Willaume, Początki Ogrodu Miejskiego w Lublinie, „Kalendarz Lubelski” na rok 1961, Lublin 1961, s. 57-61; H. GAWARECKI, O dawnym Lublinie, s. 101-102; H. GAWARECKI, Cz. GAWDZIK, Lublin, s. 66; T. MENCEL, Organizacja administracji, s. 93; TENŻE, Lublin przedkapitalistyczny, s. 209-210; C.W. DomaŃSKI, Bieczyński Feliks Tomasz, w: SBML, t. I, red. T. Radzik, J. Skarbek, A.A. Witusik, Lublin 1993, s. 29; N. PrZESMYCKA, Przeobrażenia przestrzeni wypoczynku i rekreacji w Lublinie w XIX i na poczatku XX wieku, „Zeszyty Naukowe Politechniki Śląskiej”. Seria Architektura 2006, z. 44, s. 186; G. FigIEL, Miasto między powstaniami, s. 170.
} 
Wraz z upływem lat ożywiło się budownictwo prywatne (w tym także czynszowe), obejmujące zrazu rejon Krakowskiego Przedmieścia. W 1842 r. wybudowano 12 nowych domów, w 1845 r. - 10, w 1863 r. - 22. Powoli malał odsetek budynków drewnianych, które znajdowały się głównie na przedmieściach, na rzecz murowanych - w tym także jedno- i dwupiętrowych. I tak w 1833 r. Lublin liczył ogółem 891 domów wraz z klasztorami, gmachami publicznymi i zabudowaniami prywatnymi. Tych ostatnich było w 1834 r. 745 . U schyłku lat 30. stało w mieście 895 budynków. W 1845 r. znajdowały się tu 692 domy prywatne (295 drewnianych, 397 murowanych), w 1849 r. - 701 (300 drewnianych, 401 murowanych), w 1857 r. - 754 (312 drewnianych, 442 murowane), w 1862 r. - 769 (367 drewnianych, 402 murowane). W 1860 r. reprezentacyjne ulice Lublina zdobiły 34 domy dwupiętrowe murowane i 28 jednopiętrowych - także murowanych. Poza centrum stało 16 domów jednopiętrowych drewnianych. Około 1863 r. ogół miejskiej zabudowy liczył 811 budynków ${ }^{42}$.

Lublin, przechodzący kolejny etap „melioracji”, przyciągał podróżnych powstającymi hotelami. Pierwszy z nich, Warszawski, utrzymywany przez Polla, otwarto w 1838 r. przy Krakowskim Przedmieściu. W sąsiedztwie stanął równie luksusowy Hotel Polski Ottona. Na początku lat 40. swoją gościnę oferowały poza tym śródmiejskie hotele: Angielski Meisnera (należący później do Rotkielów), Krakowski, Saski Titzowej i hotel Ślaziusa oraz liczne domy zajezdne i karczmy, przeważnie w dzielnicy żydowskiej i na przedmieściach ${ }^{43}$. W 1851 r. przy Krakowskim Przedmieściu otwarto Hotel Wiedeński. Kilka lat później Józef i Franciszka Przybylscy zmodernizowali Hotel Bawarski, zwany też „Zajazdem pod Białym Koniem”. Po rozbudowie posiadał on stajnię, wozownię i drewnianą oficynę. $\mathrm{Na}$ atrakcyjny i nowoczesny wizerunek miasta wpływały powstające restauracje (u schyłku lat 30. było ich 7) oraz zakładane przez obcokrajowców (na ogół Szwajcarów z Gryzonii) cukiernie i kawiarnie. W 1839 r. mieszkało w Lublinie dziesięciu cukierników prowadzących 7 cukierni i ośmiu właścicieli kawiarni, cztery lata później odpowiednio sześciu i jedenastu. $\mathrm{Na}$

\footnotetext{
${ }^{42}$ Raport Urzędu Municypalnego, s. 128; SGKP, t. V, s. 421; B. KoŁodZIŃSKI, Geografia Królestwa Polskiego, s. 59; S.Z. SIERPIŃSKi, Obraz miasta Lublina, s. 179; H. WIERCIEŃSKI, Opis statystyczny, s. 94; W. ĆWIK, Miasta rządowe, s. 233; T. MENCEL, Lublin przedkapitalistyczny, s. 210; J. TOMCZYK, Lublin w okresie powstania styczniowego, „Rocznik Lubelski” 4 (1961), s. 130; N. PRZESMYCKA, Lublin. Przeobrażenia urbanistyczne, s. 71.

${ }^{43}$ Postawiony w 1837 r. przy rogatce łęcznyńskiej (obecnie ulica Turystyczna) klasycystyczny zajazd „Czerwona Karczma” (w miejscu zniszczonej karczmy „Budzyń”) jest do dzisiaj jedyną pozostałością tego typu zabudowy w Lublinie. Zob. J. STUDZIŃSKi, Dzielnice przyległe do Śródmieścia, s. 355.
} 
początku lat 60. liczba cukierni „szwajcarskich” spadła do dwóch. Wśród bywalców dużym powodzeniem cieszyły się wyborne cukiernie Andrzeja Wassaliego w Rynku Starego Miasta (w latach 1843-1847 dzierżawił ją Rudolf Stampa, dużo później zaś chlubne tradycje kontynuowała kawiarnia „Czarcia Łapa”, obecnie „Muuuchio”) i rodziny Semadenich. Andrzej Semadeni założył cukiernię w kamienicy na rogu Krakowskiego Przedmieścia i ulicy Królewskiej (1836), a u schyłku lat 40. wziął w dzierżawę altanę w Ogrodzie Miejskim, gdzie sprzedawał lody, ciasta i inne delikatesy. Jego syn Kasper z czasem otworzył cukiernię przy Krakowskim Przedmieściu ${ }^{44}$. Wśród niższych warstw społecznych niebywałą popularność, wzmacnianą powabem alkoholu, utrzymywały niezmiennie szynki, których liczba na przełomie lat 30. i 40. wzrosła z 73 do $114^{45}$.

Pod wpływem omówionych wyżej zróżnicowanych procesów miastotwórczych, w następstwie przeobrażeń gospodarczych oraz rosnącej liczby ludności zmieniała się struktura społeczna i zawodowa lublinian. Wedle przybliżonych i nie do końca pewnych danych statystycznych w ostatnich latach czwartej dekady XIX wieku najwięcej osób (1125) utrzymywało się z przemysłu. Warto pamiętać, że do tej pojemnej grupy, oprócz manufakturzystów, fabrykantów i robotników, zaliczano wówczas także rzemieślników. Niemała część mieszkańców zajmowała się handlem (684). W zestawieniach zbiorczych widoczni byli rentierzy (w tym także kamienicznicy), wekslarze i inni kapitaliści (631) oraz ujmowani razem urzędnicy i duchowni (487). Mniej było właścicieli i pracowników domów zajezdnych, szynków, restauracji i hoteli (157) oraz przedstawicieli wolnych zawodów (175). Na przeciwległym biegunie „stała” lubelska biedota, obejmująca wyrobników i służących oraz poszukujących zatrudnienia parobków i dziewki służebne (1424). Na najniższych szczeblach drabiny społecznej sytuowały się prostytutki, z których usług korzystali najczęściej stacjonujący w Lublinie żołnierze. Dramatycznie przedstawiało się położenie żebraków, starców i kalek

\footnotetext{
${ }^{44}$ Związki szwajcarskich cukierników z Lublinem datują się od czasów konstytucyjnego Królestwa Polskiego. Wówczas przybyli do miasta Andrzej (Andrea) Wassali i Jan (Johann) Soldan. W ślad za nimi przyjechali: Bartłomiej Ferrari, Jakub (Giacomo) d'Alberti, Józef (Giuseppe) Biadola i Rudolf (Rodolfo) Stampa. Po upadku powstania listopadowego pojawili się kolejni Gryzończycy: Fryderyk (Friedrich) Schneller, Józef Milesi i rodzina Semadenich. Zob. S.Z. SIERPIŃski, Obraz miasta Lublina, s. VII, XIII-XIV, 117; M. PIWOWARSKA, Kawiarnie i cukiernie lubelskie 1836-1939, „Studia i Materiały Lubelskie” 15 (2008), s. 77; W. ŚLADKOWSKI, W epoce zaborów, s. 63; A. KAPROŃ, Szwajcarzy na Lubelszczyźnie, s. 20, 47-69.

${ }^{45}$ KZKML, poz. 567; S.Z. SIERPIŃSKI, Obraz miasta Lublina, s. 119, 121-122, 179; J. WILLAUMe, Poczatki ogrodu, s. 61; H. GAWARECKI, O dawnym Lublinie, s. 98-100; W. ŚladKowsKi, W epoce zaborów, s. 58, 63; M. PIWOWARSKA, Kawiarnie i cukiernie lubelskie, s. 77-78.
} 
- część z nich żyła na ulicy, pozostali, utrzymujący się także z jałmużny, znajdowali przytulisko w szpitalach (140). Za dnia wiele kobiet upadłych, żydowskiej biedoty, bezrobotnej czeladzi i wyrobników zalegało na ławkach w Ogrodzie Miejskim (Saskim), racząc się w nadmiarze alkoholem. W kolejnych dziesięcioleciach struktura społeczno-zawodowa lublinian uległa znaczącym niekiedy przeobrażeniom. W 1861 r. w przemyśle pracowały 1463 osoby, zwyżkę zanotowała branża gastronomiczno-hotelowa (219). $Z$ handlu utrzymywało się 785 osób, nie wzrósł też specjalnie odsetek reprezentantów wolnych zawodów (185). Wydatnie podniosła się natomiast liczba rentierów i kapitalistów (1185) oraz duchownych i urzędników (1081), którzy dość licznie napływali do Lublina po zniesieniu guberni podlaskiej. Wśród warstw najuboższych nieznacznie spadła liczba wyrobników i służących (1131) oraz żebraków szpitalnych $(121)^{46}$.

Odnosząc się do warstw najuboższych, warto dodać, że począwszy od lat 50. swoją działalność zaktywizowało Lubelskie Towarzystwo Dobroczynności. Pod prężnym przewodnictwem gubernatora cywilnego Stanisława Mackiewicza (1851-1861) wspierało ono biedotę, kaleki i starców oraz rodziny, które ucierpiały w wyniku drożyzny, klęsk żywiołowych oraz epidemii cholery i tyfusu. Jesienią 1853 r., z pomocą Róży z Potockich Rembielińskiej, ziemianki z Rybczewic $\mathrm{w}$ powiecie krasnostawskim, otwarto przy Krakowskim Przedmieściu ochronkę dla 40 dzieci, dwa lata później, pod patronatem Wydziału Sierot, zorganizowano sierociniec. W istniejącym

${ }^{46}$ S.Z. SierPińSKI, Obraz miasta Lublina, s. 121-125; J. Willaume, Poczatki ogrodu, s. 62; A. KiereK, Przemiany gospodarcze, s. 231; T. Mencel, Lublin w okresie, s. 134-135; H. GAWARECKI, $O$ dawnym Lublinie, s. 284; W. ŚLADKOwSKI, $W$ epoce zaborów, s. 61; B. MiKULEC, Mackiewicz Stanisław, w: SBML, t. II, red. T. Radzik, A.A. Witusik, J. Ziółek, Lublin 1996, s. 153. W ramach przedstawionej wyżej struktury społecznej i zawodowej ludność polska prezentowała się w sposób następujący: w 1845 r. szlachta osobista wylegitymowana i niewylegitymowana liczyła 1210 osób, szlachta dziedziczna - 87 osób, księża i ich rodziny wraz z duchowieństwem zakonnym - 375 osób, ogólnie ujęci mieszczanie - 2281 osób, fabrykanci i rzemieślnicy - 169 osób, kupcy i kramarze - 119 osób, dymisjonowani żołnierze z rodzinami - 57 osób, posługacze kościelni z rodzinami - 18 osób, służący, wyrobnicy i inni - 3063 osoby. W 1861 r. szlachta osobista wylegitymowana i niewylegitymowana liczyła 1638 osób, szlachta dziedziczna - 270 osób, księżą i ich rodziny wraz z duchowieństwem zakonnym - 359 osób, ogólnie ujęci mieszczanie - 1995 osób, fabrykanci i rzemieślnicy - 600 osób, kupcy i kramarze - 135 osób, dymisjonowani żołnierze z rodzinami - 250 osób, posługacze kościelni z rodzinami - 75 osób, służący, wyrobnicy i inni 3389 osób. Pozostałą część zarobkujących w mieście stanowiła w przytłaczającej liczbie ludność żydowska. Wśród starozakonnych dominowali kramarze, przekupnie i tandeciarze (w $1847 \mathrm{r}$. 45,9\%, w 1863 r. 51,9\% ogółu handlujących) oraz rzemieślnicy (w 1847 r. 57,3\%, jedenaście lat później 58,3\% całkowitej liczby drobnych wytwórców w Lublinie). Zob. T. MENCEL, Organizacja i działalność, s. 59; B. MiKULEC, Aktywność gospodarcza, s. 72, 77-78. 
od szeregu lat Domu Schronienia Starców i Kalek przebywało w 1855 r. 50 osób, pięć lat później - 44, w 1863 r. - 42, w tym sześcioro dzieci4 ${ }^{47}$.

U schyłku epoki międzypowstaniowej, w okresie reform A. Wielopolskiego i narastania patriotyczno-niepodległościowego uniesienia, sprawy porządkowania przestrzeni miejskiej i uzdrawiania finansów wzięła na swoje barki Rada Miejska. To dwunastoosobowe ciało samorządowe zostało wybrane 3 października $1861 \mathrm{r}$. (w oparciu o podpisany przez Aleksandra II 24 maja/5 czerwca tego roku pakiet czterech ukazów) i po kilku miesiącach zwłoki 1 kwietnia 1862 r. odbyło swe pierwsze posiedzenie. Pod przewodnictwem prezydenta Leopolda Wronckiego (1861-1863) zajęto się przygotowaniem budżetu na rok 1863, wyznaczono urzędników do rewizji kasy miejskiej, podjęto też problem nieregularności wpływów podatkowych i likwidacji forszusów. W ramach szeroko zakrojonych prac zamierzano wybrukować Podzamcze, ulice Jezuicką i Nadstawną oraz przebrukować Krakowskie Przedmieście i kilka sąsiednich przecznic. Zaplanowano poza tym budowę 15 żelaznych pomp ssąco-tłoczących, które miały zastąpić wysłużone i niewydolne studnie drewniane. Projektowano również przeprowadzenie nowych kanałów ściekowych, zaopatrzenie Lublina w lepsze utensylia przeciwpożarowe i zaprowadzenie stałej straży ogniowej oraz stworzenie miejskiej służby do oczyszczania ulic i miasta. Wobec wybuchu powstania styczniowego większość z tych planów, skupionych niestety w dalszym ciągu głównie na śródmieściu, nie doczekała się realizacji ${ }^{48}$.

Tak oto $\mathrm{w}$ przybliżeniu przedstawiał się polistopadowy obraz Lublina postrzegany przez pryzmat gospodarki finansowej, przekształceń urbanistycznych i ogólnej charakterystyki ludności. Miasto, dotkliwie okaleczone w czasie powstania listopadowego, leczyło rany powoli, wolno też rosła

${ }^{47}$ J. CHOJNACKI, Lubelskie Towarzystwo Dobroczynności w latach 1852-1860, „Region Lubelski” 3 (5) (1988), s. 217-226; Cz. KĘPSKI, Lubelskie Towarzystwo Dobroczynności 1815-1852, Lublin 1990, s. 22-29; L. ŚwIETLICKI, Dwory nad Giełczwia, Lublin 1999, s. 55.

${ }^{48}$ T. MENCEL, Organizacja i działalność, s. 99-103, 107; TENŻE, Lublin przedkapitalistyczny, s. 214-215; W.W. ĆWIK, J. REDER, Lubelszczyzna, s. 98-99; R. BENDER, Powstanie czy samorząd?, s. 100, 103-105; D. SZPOPER, Reforma samorządowa w Królestwie Polskim w latach 1861-1862, „Czasopismo Prawno-Historyczne” 66 (2014), z. 1, s. 152. 
liczba mieszkańców. W następstwie działań wojennych i długotrwałej zaborczej okupacji, a później w wyniku rządów skorumpowanych i nieudolnych włodarzy z carskiego nadania finanse Lublina uległy załamaniu. Wraz z powolnym odzyskiwaniem stabilizacji budżetowej kontynuowano przerwane wojną działania modernizacyjne charakterystyczne dla nowożytnych przeobrażeń. Na uwypuklenie zasługują tu zróżnicowane prace porządkowe związane z regulowaniem i brukowaniem ulic, budową i oczyszczaniem podziemnych kanałów ściekowych, stawianiem nowych studni i latarni. Sukcesywnie rozbierano zabudowę grożącą zawaleniem, gruntownej restauracji poddano też szereg domów, kościołów i większych zespołów sakralnych. $\mathrm{Z}$ upływem lat ożywiło się budownictwo mieszkaniowe (w tym także czynszowe). Rosła liczba domów murowanych, w śródmieściu nierzadko reperzentacyjnych, kilkupiętrowych. Należy podkreślić, że te podążające z duchem czasu przeobrażenia w sposób widoczny dotknęły jedynie miasta chrześcijańskiego. Szczątkowo objęto nimi rejon dzielnicy żydowskiej zapomnianej przez władze miejskie i pozostającej na uboczu procesów rozwojowych. Nie sięgnęły też one do przedmieść - na ogół drewnianych i biednych, pełnych przekupniów, wyrobników i „ludzi luźnych”, gdzie „mieszczańskie” lepianki sąsiadowały z obsianymi zbożem niwami, prymitywnie urządzonymi stodołami, chlewami i oborami.

Pod względem demograficznym Lublin w okresie międzypowstaniowym utrzymał swój narodowościowy i wyznaniowy dualizm. Poza Polakami i Żydami mieszkały tu niewielkie skupiska osiedleńców ewangelickich oraz śladowe ilości grekokatolików i wyznawców prawosławia. W wyniku przenikania się zróżnicowanych czynników (społecznych, gospodarczo-ekonomicznych, politycznych i administracyjnych) rosła przy tym liczba ludności niestałej, różnicowała się wreszcie struktura społeczno-zawodowa lublinian.

Wszystkim tym przekształceniom i przeobrażeniom, nadającym ton czy współtworzącym kondycję gospodarczą miasta, towarzyszyła przez lata atmosfera paskiewiczowskiego ucisku. Pod rządami wojskowo-policyjnymi definiowała ona konteksty i tworzyła ramy dla niełatwych popowstaniowych dekad. Później, na fali krótkotrwałej liberalizacji, w okresie tzw. rewolucji moralnej i „polskich czasów”, w atmosferze patriotyczno-religijnego ożywienia i krzepnącej konspiracji starano się kontynuować dzieło reform, ale kres tym usiłowaniom położył wybuch insurekcji styczniowej. 


\section{BIBLIOGRAFIA}

\section{ŹRÓDŁA ARCHIWALNE}

Archiwum Główne Akt Dawnych, Komisja Rządowa Spraw Wewnętrznych, sygn. 7088.

\section{ŹRÓDŁA DRUKOWANE I PUBLICYSTYKA Z EPOKI}

Dziennik Praw Królestwa Polskiego, t. XX, b.m.d.w.

Dziennik Praw Królestwa Polskiego, t. XXX, b.m.d.w.

Dziennik Praw Królestwa Polskiego, t. XXXIV, b.m.d.w.

Raport Urzędu Municypalnego miasta Lublina do Komisji Województwa Lubelskiego z działalności za rok 1833, w: Lublin $w$ dokumencie 1317-1967, oprac. Franciszek Cieślak, Henryk Gawarecki, Maria Stankowa, Lublin: Wydawnictwo Lubelskie 1976.

\section{OPRACOWANIA, PAMIĘTNIKI I SŁOWNIKI}

BAŁABAN Majer, Żydowskie miasto w Lublinie, Lublin: Wydawnictwo FIS 1991.

BednARSKI Waldemar Wojciech, Straty wojenne Lubelszczyzny i Podlasia w powstaniu listopadowym, w: W kręgu zainteresowań naukowych profesora Tadeusza Mencla, red. A. Koprukowniak, Lublin: Wydawnictwo UMCS 1999.

BEDNARSKI Waldemar Wojciech, Z dziejów klęsk elementarnych na Podlasiu w latach 1815-1831, „Radzyński Rocznik Humanistyczny” 1 (2001).

Bender Ryszard, Powstanie czy samorzad? Rady miejskie i powiatowe w Lubelskiem 1961-1863, Lublin: Lubelskie Towarzystwo Naukowe 1998.

BownIK Zygmunt, Kupiectwo lubelskie 1317-1959, Lublin: Wojewódzkie Zrzeszenie Prywatnego Handlu i Usług 1960.

BuCZYŃSKI Mieczysław, Nazwy dzielnic i przedmieść Lublina, „Rocznik Lubelski” 5 (1962).

ChOJNACKI Jerzy, Lubelskie Towarzystwo Dobroczynności w latach 1852-1860, „Region Lubelski” 3 (5) (1988).

CZEREPIŃSKA Jadwiga, MichalSKA Grażyna, STUDZIŃSKi Jacek, Zespót kościoła Świętej Trójcy w Lublinie, w: Parafia ewangelicko-augsburska w Lublinie. Historia - tradycja-wspótczesność, red. Dariusz Chwastek, Lublin: Lemon Studio 2007.

CZEREPIŃSKA Jadwiga, MichalSKa Grażyna, UlJASz Adrian, Ewangelicy lubelscy, w: Parafia ewangelicko-augsburska w Lublinie. Historia - tradycja - wspótczesność, red. Dariusz Chwastek, Lublin: Lemon Studio 2007.

ĆwIK Władysław, Miasta rządowe małopolskiej części Królestwa Polskiego 1815-1866 (stan gospodarczo-społeczny”, „Rocznik Lubelski” 10 (1967).

ĆwIK Władysław, Z dziejów Lubartowa w latach 1796-1866, w: Lubartów. Z dziejów miasta i regionu, red. Stanisław Tworek, Lublin: Wydawnictwo Lubelskie 1977.

ĆwIK Władysław, Reder Jerzy, Lubelszczyzna. Dzieje rozwoju terytorialnego, podziatów administracyjnych i ustroju władz, Lublin: Wydawnictwo Lubelskie 1977.

Danczowska Halina, Dziesiata. Dzieje dzielnicy Lublina, Lublin: Wydawnictwo - Drukarnia Liber Duo Wanda i Józef Rumińscy 2007.

DoBrZAŃSKI Jan, Życie umystowe, szkolnictwo i oświata w I połowie XIX wieku, w: Dzieje Lublina. Próba syntezy, t. I, red. Jan Dobrzański, Jerzy Kłoczowski, Józef Mazurkiewicz, Lublin: Wydawnictwo Lubelskie 1965.

DOMAŃSKI Cezary Wojciech, Bieczyński Feliks Tomasz, w: Stownik Biograficzny Miasta Lublina, t. I, red. Tadeusz Radzik, Jan Skarbek, Adam A[ndrzej] Witusik, Lublin: Wydawnictwo UMCS 1993. 
DubrowsKa Małgorzata, Od „Jerozolimy Królestwa Polskiego” do miejsca pamięci - żydowski Lublin, „Studia Europaea Gnesnensia” 1-2 (2010).

FIGIEL Grzegorz, Miasto między powstaniami i w czasie styczniowej insurekcji, w: Lublin. 700 lat dziejów miasta, red. Grzegorz Figiel, Ryszard Szczygieł, Wiesław Śladkowski, Lublin: Wojewódzka Biblioteka Publiczna im. Hieronima Łopacińskiego 2017.

GAWARECKA Maria, Prezydenci miasta Lublina w latach 1830-1880, „Życie Lubelskie” 1949, nr 25.

GAWARECKI Henryk, O dawnym Lublinie. Szkice z przeszłości miasta, Lublin: Wydawnictwo Lubelskie 1974.

GAWARECKI Henryk, Porównawczy opis Lublina z lat 1822 i 1899 Seweryna Liniewskiego, „Studia i Materiały Lubelskie". Historia Sztuki 1-2 (1963).

GAWARECKI Henryk, Stanistaw Krzesiński: „Dwa wrażenia..., czyli Lublin jakim byt w roku 1827 i jakim jest w roku 1877”, „Rocznik Lubelski” 1 (1958).

GAWARECKI Henryk, GAWDZIK Czesław, Lublin, Warszawa: Wydawnictwo „Arkady” 1959.

GMiTER Małgorzata, KoTOwski Bogdan, KuCHARSKa Krystyna, LASKOwsKa Bibianna, POPEK Leon, Cmentarz rzymskokatolicki przy ul. Lipowej w Lublinie, Lublin: Krajowa Agencja Wydawnicza 1990.

GMitereK Henryk, Lublin jurydyk i Trybunału Koronnego, w: Lublin. 700 lat dziejów miasta, red. Grzegorz Figiel, Ryszard Szczygieł, Wiesław Śladkowski, Lublin: Wojewódzka Biblioteka Publiczna im. Hieronima Łopacińskiego 2017.

Historia Lublina $w$ liczbach, oprac. Andrzej Jakubowski, Urszula Bronisz, Elżbieta Łoś, Lublin: Urząd Statystyczny 2018.

Historia Polski w liczbach. Ludność. Terytorium, red. Andrzej Jezierski, Warszawa: Zakład Wydawnictw Statystycznych 1994.

JANCZAK Julian Karol, Statystyka ludności Królestwa Polskiego (1830-1844), „Przeszłość Demograficzna Polski" 16 (1985).

JelONeK Adam, Ludność miast i osiedli typu miejskiego na ziemiach polskich od 1810 do 1960 r., Warszawa: IGiPZ PAN 1967.

KACZYŃSKa Elżbieta, DREWNiAK Dariusz, Ochrana. Carska policja polityczna, Warszawa: Wydawnictwo „Bellona” 1993.

KAPROŃ Andrzej, Francuzi w dziewiętnastowiecznym Lublinie, Lublin: Wydawnictwo „Polihymnia” 2003.

KAPROŃ Andrzej, Szwajcarzy na Lubelszczyźnie w latach 1815-1914, Szczecin: Wydawnictwo „My Book" 2009.

Katalog Zasobów Kulturowych Miasta Lublina, oprac. Marek Stasiak, Lublin: Urząd Miejski w Lublinie 1999.

KĘPSKI Czesław, Lubelskie Towarzystwo Dobroczynności 1815-1852, Lublin: Wydawnictwo UMCS 1990.

KiEREK Aleksander, Przemiany gospodarcze w Lublinie w latach 1795-1864, w: Dzieje Lublina. Próba syntezy, t. I, red. Jan Dobrzański, Jerzy Kłoczowski, Józef Mazurkiewicz, Lublin: Wydawnictwo Lubelskie 1965.

KIEREK Aleksander, Rozwój Lublina w latach 1864-1914, w: Dzieje Lublina. Próba syntezy, t. I, red. Jan Dobrzański, Jerzy Kłoczowski, Józef Mazurkiewicz, Lublin: Wydawnictwo Lubelskie 1965.

KIEREK Aleksander, Rozwój przestrzenny i stan urządzeń komunalnych m. Lublina w latach 18701915, „Rocznik Lubelski” 14 (1971).

KIrSzRot Jakub, Prawa Żydów w Królestwie Polskim. Zarys historyczny, Warszawa: Zarząd Warszawskiej Gminy Starozakonnych 1917. 
Kociuba Dagmara, Rozwój przestrzenny Lublina od średniowiecza do wspótczesności, w: Lublin. Historia, społeczeństwo, gospodarka, red. Wojciech Janicki, Lublin: Wydawnictwo UMCS 2018.

KoŁodZIŃSKI Bolesław, Geografia Królestwa Polskiego podtug najnowszych źródeł skreślona, Warszawa: Aleksander Lewiński 1863.

KOPRUKOWNIAK Albin, Obraz miasteczek Lubelskich 1795-1918, w: Miejskie spoleczności lokalne w Lubelskiem 1795-1918, red. Albin Koprukowniak, Lublin: Lubelskie Towarzystwo Naukowe 2000.

KuwAŁeK Robert, Lubelskie synagogi, w: Robert KuWAŁeK, Wiesław WysoK, Jerozolima Królestwa Polskiego, Lublin: Stowarzyszenie „Dialog i Współpraca” 2001.

KuWAŁEK Robert, Społeczność żydowska na Wieniawie w XIX i XX wieku, w: Żydzi w Lublinie. Materiały do dziejów społeczności żydowskiej w Lublinie, t. II, red. Tadeusz Radzik, Lublin: Wydawnictwo UMCS 1998.

KuWAŁEK Robert, Społeczność żydowska w XIX i XX wieku, w: Robert KuWAŁEK, Wiesław WysoK, Jerozolima Królestwa Polskiego, Lublin: Stowarzyszenie „Dialog i Współpraca” 2001.

LubowIECKI Ignacy, Statystyka województwa lubelskiego, Lublin: [b.w.] 1824.

ŁOPACIŃSKI Hieronim, Podziały administracyjne teraźniejszej guberni lubelskiej w różnych czasach, „Pamiętnik Lubelski. Kalendarz Ilustrowany” na rok 1904, Lublin 1904.

ŁoZIŃSKI Ryszard, Zemborzyce. Szkice z dziejów wsi i dzielnicy miasta, Lublin: Petit i Rada Osiedla Zemborzyce 2005.

M.A.R. [Ronikierowa Maria Antonina], Ilustrowany przewodnik po Lublinie, Warszawa: Nakładem autora 1901.

MAZURKIEWICZ Józef, Własność $i$ zmiany $w$ stosunkach własnościowych $w$ Lublinie $w$ latach sześćdziesiatych XIX stulecia, „Rocznik Lubelski” 6 (1963).

Mencel Tadeusz, Działalność władz cywilnych województwa lubelskiego w okresie powstania listopadowego, „Rocznik Lubelski” 5 (1962).

Mencel Tadeusz, Kajetan Morozewicz (1792-1869) prezes „Narodowej” Komisji Województwa Lubelskiego w powstaniu listopadowym, ,Rocznik Lubelski” 20 (1980).

Mencel Tadeusz, Lublin przedkapitalistyczny, w: Dzieje Lublina. Próba syntezy, t. I, red. Jan Dobrzański, Jerzy Kłoczowski, Józef Mazurkiewicz, Lublin: Wydawnictwo Lubelskie 1965.

MenCEL Tadeusz, Lublin w okresie walk narodowowyzwoleńczych 1795-1864, w: Lublin 13171967, red. Henryk Zins, Lublin: Wydawnictwo Lubelskie 1967.

Mencel Tadeusz, Między powstaniami (1831-1864), w: Dzieje Lubelszczyzny, t. I, red. Tadeusz Mencel, Warszawa: Państwowe Wydawnictwo Naukowe 1974.

MenCEL Tdeusz, Organizacja i działalność administracji miejskiej w Lublinie w latach 1809-1866, „Rocznik Lubelski” 4 (1961).

Mencel Tadeusz, Powstanie listopadowe na Lubelszczyźnie w świetle raportu Komisji Województwa Lubelskiego z 9 czerwca 1834 r., „Rocznik Lubelski” 22 (1980).

Mencel Tadeus, Wieś pańszczyźniana $w$ Królestwie Polskim $w$ połowie XIX wieku, Lublin: Wydawnictwo Lubelskie 1988.

MIKULEC Bronisław, Aktywność gospodarcza i filantropijna ewangelików w Lublinie w XIX wieku, w: Ku Niepodległej. Ścieżki polskie i francuskie 1795-1918, red. Małgorzata Willaume, Lublin: Wydawnictwo UMCS 2005.

MiKULEC Bronisław, Aktywność gospodarcza ludności żydowskiej Lublina w latach 1815-1864, w: Żydzi w Lublinie. Materiały do dziejów społeczności żydowskiej w Lublinie, t. II, red. Tadeusz Radzik, Lublin: Wydawnictwo UMCS 1995.

MikUlec Bronisław, Kośmiński Michat, w: Słownik Biograficzny Miasta Lublina, t. III, red. Tadeusz Radzik, Adam A[ndrzej] Witusik, Jan Ziółek, Lublin: Wydawnictwo UMCS 2009. 
MikUlec Bronisław, Mackiewicz Stanisław, w: Stownik Biograficzny Miasta Lublina, t. II, red. Tadeusz Radzik, Adam A[ndrzej] Witusik, Jan Ziółek, Lublin: Wydawnictwo UMCS 1996.

MikUleC Bronisław, Wśród pionierów polskiego przemysłu, w: Lublin w dziejach i kulturze Polski, red. Tadeusz Radzik i Adam A[ndrzej] Witusik, Lublin: Krajowa Agencja Wydawnicza i Polskie Towarzystwo Historyczne. Oddział w Lublinie 1997.

MıŁKOwSKi Stanisław, Opis Królestwa Polskiego pod względem geografii, statystyki i historii, Warszawa: [b.w.] 1861.

PALIMĄKA Anita, Zmiany w sytuacji prawnej Żydów na ziemiach zaboru rosyjskiego w pierwszej połowie XIX wieku (do 1862 r.), ,Śląskie Studia Historyczno-Teologiczne” 2 (2009), z. 1.

Pamiętniki Fryderyka hrabiego Skarbka, Poznań: J[an] K[onstanty] Żupański 1878.

Pamiętnik Ignacego Baranowskiego (1840-1862), wyd. Adam Wrzosek, Poznań: Gebethner i Wolf 1923.

Pamiętnik zjazdu bytych wychowańców Szkót Lubelskich, Lublin: Komisja Zjazdu 1926.

PIĄTKOWSKI Sebastian, Modernizator czy ciemiężca? Generat Teodor Rüdigier jako donatariusz lubelski, w: Studia nad ziemiaństwem w XIX i XX wieku, red. Albin Koprukowniak i Zofia Gołębiowska, Lublin: Lubelskie Towarzystwo Naukowe 2008.

PIwOWARSKA Magdalena, Kawiarnie i cukiernie lubelskie 1836-1939, „Studia i Materiały Lubelskie" 15 (2008).

PRZEGAliŃSKi Andrzej, W źródłach zapisane. Dzieje Dąbrowicy i Plouszowic w pierwszej połowie XIX wieku w świetle dokumentów hipotecznych i notarialnych, w: Z dziejów Jastkowa i okolic. Studia i materiaty, t. V, red. Cezary Taracha, Lublin: Wydawnictwo „Werset” 2017.

PrZeSMYCKA Natalia, Lublin. Przeobrażenia urbanistyczne 1815-1939, Lublin: Politechnika Lubelska 2012.

PRZESMYCKa Natalia, Przeobrażenia przestrzeni wypoczynku i rekreacji w Lublinie $w$ XIX i na poczatku XX wieku, „Zeszyty Naukowe Politechniki Śląskiej”. Seria Architektura 2006, z. 44.

RADZIK Tadeusz, Żyli z nami, w: Lublin w dziejach i kulturze Polski, red. Tadeusz Radzik i Adam A[ndrzej] Witusik, Lublin: Krajowa Agencja Wydawnicza i Polskie Towarzystwo Historyczne. Oddział w Lublinie 1997.

RostwOROwSKI Stanisław Jan, Monografia rodziny Rostworowskich. Lata 1386-2012, t. II, Warszawa: Oficyna Wydawnicza „Rytm” 2013.

SADURSKI Irenusz, Regulaminy $i$ wymogi obowiązujące uczniów Gimnazjum Lubelskiego $w$ dobie międzypowstaniowej, „Rocznik Lubelski” 43 (2017).

SIERPIŃSKI Seweryn Zenon, Obraz miasta Lublina, Warszawa: [b.w.] 1839.

SKARBEK Jan, Województwo lubelskie $w$ powstaniu listopadowym 1830-1831, cz. 2, Lublin: Wydawnictwo KUL 2013.

SKARBEK Jan, Żydzi Lublina podczas powstania listopadowego 1830-1831, w: Żydzi w Lublinie. Materiaty do dziejów społeczności żydowskiej w Lublinie, t. II, red. Tadeusz Radzik, Lublin: Wydawnictwo UMCS 1998.

Słownik Geograficzny Królestwa Polskiego i innych krajów słowiańskich, t. V, red. Filip Sulimierski, Bronisław Chlebowski, Władysław Walewski, Warszawa: Nakładem Filipa Sulimierskiego i Władysława Walewskiego 1884.

Stankiewicz Zbigniew, Spór o Rury Brygidkowskie. Przyczynek do dziejów rozwoju terytorialnego Lublina w XIX wieku, „Rocznik Lubelski” 13 (1970).

STUDZIŃSKI Jacek, Dzielnice przyległe do Śródmieścia, w: Lublin. Przewodnik, red. Piotr Kawałko, Zbigniew Nestorowicz i in., Lublin: Wydawnictwo Archidiecezji Lubelskiej „Gaudium” 2012.

SzMYT Andrzej, Krzemieńczanin Karol Kaczkowski-naczelny lekarz armii powstańczej, w: Powstanie listopadowe 1830-1831. Dzieje - historiografia - pamięć, red. Tadeusz Skoczek, Warszawa: Muzeum Niepodległości w Warszawie 2015. 
SzPOPER Dariusz, Reforma samorządowa w Królestwie Polskim w latach 1861-1862, „Czasopismo Prawno-Historyczne" 66 (2014), z. 1.

Szuchta Robert, 1000 lat historii Żydów polskich. Podróż przez wieki, Warszawa: Muzeum Historii Żydów Polskich Polin 2015.

ŚLADKOwSKI W., Lublin powstańczy, w: Lublin w dziejach i kulturze Polski, red. Tadeusz Radzik i Adam Andrzej Witusik, Lublin: KAW i Polskie Towarzystwo Historyczne 1997.

ŚLADKOwSKI Wiesław, Rozwój przestrzenny Lublina w XIX i XX stuleciu, w: Stare i nowe struktury spoleczne w Polsce, t. IX: Przestrzeń antropogeniczna miasta Lublina. Waloryzacja, Wytwarzanie. Użytkowanie, red. Józef Styk, Lublin: Wydawnictwo UMCS 2009.

ŚLADKOWSKI Wiesław, Sprawozdanie gubernatora lubelskiego za rok 1863, „Rocznik Lubelski” 6 (1963).

ŚlADKOwSKI Wiesław, $W$ epoce zaborów, w: Tadeusz RADZIK, Wiesław ŚLADKOWSKI, Grzegorz Wóscikowski, Włodzimierz WóscIKOWski, Lublin. Dzieje miasta, t. II: XIX-XX wiek, Lublin: Towarzystwo Miłośników Lublina 2000.

ŚladKowsKi Wiesław, W Księstwie Warszawskim i w Królestwie Polskim 1809-1830, w: Lublin. 700 lat dziejów miasta, red. Grzegorz Figiel, Ryszard Szczygieł, Wiesław Śladkowski, Lublin: Wojewódzka Biblioteka Publiczna im. Hieronima Łopacińskiego 2017.

ŚLADKOwSKI Wiesław, Zamość pod znakiem Marsa, w: Czterysta lat Zamościa, red. Jerzy Kowalczyk, Wrocław-Warszawa-Kraków-Gdańsk-Lódź: Zakład Narodowy im. Ossolińskich 1983.

ŚwIETLICKI Lucjan, Dwory nad Giełczwia, Lublin: Wydawnictwo „Norbertinum” 1999.

TAŹBIREK Dariusz, Lublin w czasie powstania listopadowego, Lublin: Lubelskie Towarzystwo Naukowe i Wydawnictwo „Olech” 2009.

TOMCZYK Józef, Lublin w okresie powstania styczniowego, „Rocznik Lubelski” 4 (1961).

WIECH Stanisław, Żandarmeria rosyjska i jej raporty, w: Sytuacja polityczna Królestwa Polskiego $w$ świetle tajnych raportów naczelników Warszawskiego Okręgu Żandarmerii z lat 1867-1872 i 1878, oprac. Stanisław Wiech i Wiesław Caban, Kielce: Wydawnictwo WSP im. J. Kochanowskiego 1999.

WIERCIEŃSKI Henryk, Opis statystyczny guberni lubelskiej, Warszawa: [b.w.] 1901.

WIERCIEŃSKI Henryk, Pamiętniki, oprac. Andrzej Zajączkowski, Lublin: Wydawnictwo Lubelskie 1973.

Willaume Juliusz, Początki Ogrodu Miejskiego w Lublinie, „Kalendarz Lubelski” na rok 1961, Lublin 1961.

WILlAUME Juliusz, Z dziejów wsi lubelskiej przed uwłaszczeniem, „Annales UMCS”. Sec. F, vol. X, 1955.

WiŚNIEWSKI Stanisław, Pod rządami zaborców 1795-1918, w: Dzieje Końskowoli, red. Ryszard Szczygieł, Lublin: Końskowolskie Towarzystwo Regionalne 1988.

WITKOWSKI Wojciech, Podlubelska Wieniawa, ,Rocznik Lubelski” 14 (1971).

WOLSKI Ludwik, Materiaty do statystyki Królestwa Polskiego, „Biblioteka Warszawska” t. II, 1850.

ZAJewsKi Władysław, Powstanie listopadowe 1830-1831, w: Stefan KIENIEWICZ, Andrzej ZAHORSKI, Władysław ZAJEWSKI, Trzy powstania narodowe: kościuszkowskie, listopadowe, styczniowe, Warszawa: Spółdzielnia Wydawniczo-Handlowa „Książka i Wiedza” 2000.

ZIELIŃSKI Władysław Kornel, Monografia Lublina, Lublin: Drukarnia J. Herszenhorna i M. Sznajdermessera 1878.

ZIELIŃSKI Władysław Kornel, Opis Lublina jako przewodnik dla zwiedzajacych miasto i jego okolice, Lublin 1876.

Z przeszłości kulturowej Lubelszczyzny. Inwentarz topograficzno-rzeczowy zabytków województwa lubelskiego, oprac. Irena Rolska-Boruch, Lublin: Wydawnictwo Archidiecezji Lubelskiej „Gaudium" 2002. 


\author{
ZANIM DO LUBLINA ZAWITAŁ WIELKI PRZEMYSŁ \\ - DZIEJE GOSPODARCZE MIASTA W EPOCE \\ MIĘDZYPOWSTANIOWEJ (1831-1863). \\ STUDIUM SYNTETYCZNE \\ Streszczenie
}

Niniejszy artykuł, pomyślany jako tekst dwuczęściowy, ma na celu przybliżenie czytelnikom dziejów gospodarczych Lublina w epoce dla Królestwa Polskiego szczególnej: po upadku powstania listopadowego, w okresie nasilającego się paskiewiczowskiego ucisku (1832-1856) i kilku lat odwilży poprzedzających wybuch insurekcji styczniowej. Ówczesny rozwój miasta oraz kondycja przemysłu, rzemiosła i handlu, w zestawieniu z rozkwitem Lublina w epoce postyczniowego półwiecza, były niewątpliwie skromne i niezbyt efektowne. $\mathrm{Z}$ tych względów rola tego okresu w dyskusjach o gospodarczych wzlotach grodu nad Bystrzycą bywa niekiedy pomniejszana. Niesłusznie. W epoce międzypowstaniowej miasto rozwijało się wprawdzie umiarkowanie dynamicznie, ale i wówczas dokonywały się przecież ważkie przekształcenia urbanistyczne, nie brakło też innowatorów oraz ciekawych, choć nie zawsze fortunnych inicjatyw przemysłowych, wartych jednak przypomnienia.

Słowa kluczowe: historia gospodarcza; Lublin; zabory.

\title{
BEFORE LUBLIN ENTERED THE GREAT INDUSTRY: THE ECONOMIC HISTORY OF THE CITY IN THE INTER-UPRISING ERA (1831-1863) \\ SYNTHETIC STUDY
}

\section{S u m m a ry}

This article, conceived as a two-part text, aims to familiarize the Lublin's economic history in the period for the Kingdom of Poland unique: after the fall of the November Uprising, during the period of Paskiewicz's oppression (1832-1856) and a few years preceding the outbreak of the January insurrection. The contemporary development of the city and the condition of its industry, trade and commerce, in comparison with the economic boom of Lublin in the next fifty years were undoubtedly modest and not very effective. For these reasons, the role of this era in discussions about the economic rise of Lublin is being sometimes diminished. Wrongly. In the inter-uprising era the city grew moderately dynamically, but even then there were important urban transformations, innovators and interesting but not always fortunate industrial initiatives as well. It is also worth to mention.

Key words: economic history; Lublin; partitions of Poland. 